\title{
Effects of afforestation with Pinus sylvestris var. mongolica plantations combined with enclosure management on soil microbial community
}

\author{
Jiaojiao Deng ${ }^{1,2}$, Yongbin Zhou ${ }^{1,2}$, Wenxu Zhu ${ }^{1,2}$, You Yin ${ }^{\text {Corresp. } 1,2}$ \\ ${ }^{1}$ College of Forestry, Shenyang Agricultural University, Shenyang, Liaoning, China \\ 2 Research Station of Liaohe-River Plain Forest Ecosystem, Chinese Forest Ecosystem Research Network (CFERN), Shenyang Agricultural University, \\ Tieling, Liaoning, China \\ Corresponding Author: You Yin \\ Email address: 1993500012@syau.edu.cn
}

Grazing and litter removal can alter understory structure and composition after afforestation, posing a serious threat to sustainable forest development. Enclosure is considered to be an effective measure to restore degraded forest restoration. However, little is known about the dynamics of soil nutrients and microbial communities during the forest restoration process. In the present study, the effects of Arachis hypogaea (AH), Pinus sylvestris var. mongolica (PSM), and Pinus sylvestris var. mongolica with enclosure (PSME) on soil chemical properties and soil microbial communities were studied in Zhanggutai, Liaoning Province, China. The results showed that PSME could remarkably contribute to improve soil total $\mathrm{C}$, total $\mathrm{N}$, and total $\mathrm{P}$ compared to PSM and $\mathrm{AH}$. Additionally, PSM could clearly increase the soil bacterial community diversity and fungal Chaol index and ACE index. Additionally, PSME could further increase soil Chaol index and ACE index of soil bacteria. Soil total $\mathrm{C}$, total $\mathrm{N}$ and available $\mathrm{N}$ were the main factors related to soil microbial diversity. Actinobacteria and Ascomycota were the predominant bacterial and fungal phyla, respectively. Specifically, PSME could increase the relative abundances of Actinobacteria, Gemmatimonadetes, Ascomycota and Mortierellomycota and decreased the relative abundances of Acidobacteria, Chloroflexi and Basidiomycota than PSM. PSM and PSME could clearly change soil microbial communities compared with $\mathrm{AH}$, and PSME could remarkably shift soil fungal communities than PSM. What's more, the soil microbial community structure were affected by multiple edaphic chemical parameters. It can be seen that afforestation combined with enclosed management potentially regulate microbial properties through shifting the soil properties. This study can provide new ideas for further understanding the impact of enclosure on Pinus sylvestris var. Mongolica and provide theoretical support for the management of Pinus sylvestris var. Mongolica. 
1 Effects of afforestation with Pinus sylvestris var. mongolica plantations combined with enclosure

2 management on soil microbial community

3 Jiaojiao Deng ${ }^{1,2}$, Yongbin Zhou ${ }^{1,2}$, Wenxu Zhu ${ }^{1,2}$, You Yin ${ }^{1,2^{*}}$

$4 \quad{ }^{1}$ College of Forestry, Shenyang Agricultural University, Shenyang, Liaoning, China.

$5 \quad{ }^{2}$ Research Station of Liaohe-River Plain Forest Ecosystem, Chinese Forest Ecosystem

6 Research Network (CFERN), Shenyang Agricultural University, Tieling, Liaoning, China.

7

8

*Corresponding author

You Yin

No. 120, Dongling Road, Shenhe Distinct, Shenyang, Liaoning Provience, 110161, China

Email address: 1993500012@syau.edu.cn 


\section{Abstract}

Grazing and litter removal can alter understory structure and composition after afforestation, posing a serious threat to sustainable forest development. Enclosure is considered to be an effective measure to restore degraded forest restoration. However, little is known about the dynamics of soil nutrients and microbial communities during the forest restoration process. In the present study, the effects of Arachis hypogaea (AH), Pinus sylvestris var. mongolica (PSM), and Pinus sylvestris var. mongolica with enclosure (PSME) on soil chemical properties and soil microbial communities were studied in Zhanggutai, Liaoning Province, China. The results showed that PSME could remarkably contribute to improve soil total C, total $\mathrm{N}$, and total P compared to PSM and AH. Additionally, PSM could clearly increase the soil bacterial community diversity and fungal Chaol index and ACE index. Additionally, PSME could further increase soil Chaol index and ACE index of soil bacteria. Soil total $\mathrm{C}$, total $\mathrm{N}$ and available $\mathrm{N}$ were the main factors related to soil microbial diversity. Actinobacteria and Ascomycota were the predominant bacterial and fungal phyla, respectively. Specifically, PSME could increase the relative abundances of Actinobacteria, Gemmatimonadetes, Ascomycota and Mortierellomycota and decreased the relative abundances of Acidobacteria, Chloroflexi and Basidiomycota than PSM. PSM and PSME could clearly change soil microbial communities compared with AH, and PSME could remarkably shift soil fungal communities than PSM. What's more, the soil microbial community structure were affected by multiple edaphic chemical parameters. It can be seen that afforestation combined with enclosed management potentially regulate microbial properties through shifting the soil properties. This study can provide new ideas for further understanding the impact of enclosure on Pinus sylvestris var. Mongolica and provide theoretical support for the management of Pinus sylvestris var. Mongolica.

Keywords: Afforestation; Pinus sylvestris var. mongolica; Enclosure; Soil microbial community

\section{Introduction}


53 The arid and semi-arid regions cover an area of about 4 billion hectares, accounting for about $30 \%$

54 of the terrestrial land area within the globe (Lal, 2001). These areas have been continuously threatened by soil degradation and desertification due to natural and human interference such as climate variation, over-cultivation intensity, overgrazing of livestock for decades, vegetation destroyed by firewood (He et al., 2015; Haberl et al., 2007; Li et al., 2018), which may lead to a range of severely ecological problems, such as loss of biodiversity, soil erosion, global soil C loss (Lal, 2001). It has been estimated that land degradation caused by desertification affects onequarter of the world's land surface, containing one-fifth of the world's population, mostly living in developing countries (D’Odorico et al., 2013). In view of this, a series of ecological restoration programs have been implemented, among which, re-vegetation through afforestation is one of the most commonly used techniques (Nunezmir et al., 2015) and an effective method to combat desertification (Gao et al., 2002), and increase soil C and N storages (Su et al., 2005; Hu et al., 2008; Chen et al., 2010), especially in arid and semi-arid regions.

While, the effects of forest management and disturbance can be extended to change the structure and function of forest ecosystems over time (Fox, 2000). For a long time, it has been believed that forests around the world principally have been threatened by logging for fuel or industrial use and land reclamation of pasture and agriculture (Lindquist et al., 2012). Nevertheless, in some regions, litter removal and livestock grazing could endanger long-term protection of forest (Fleischner, 1994; Belsky \&Blumenthal, 1997). For example, throughout the $19^{\text {th }}$ century, the collection of litter from managed forests as fuel and farming have been widely practiced in many countries, still existing in some regions (Hofmeister et al., 2008; Chevasco et al., 2018), which may have negative effect on nutrient cycling and forest productivity. In addition, the use of forests by livestock could have substantial impacts on the structure and dynamics of forests, soil microenvironment, land vegetation cover, water availability, plant establishment (Yates et al., 2000), soil quality (Li et al., 2012), wildlife conservation and the other ecosystem service functions (Vargas et al., 2010). In view of this, a series of policies of ecological conservation have been launched for the sake of reducing its negative impact on forests (Mu et al., 2013).

Enclosure fencing is identified as an effective management practice to enhance the carbon sequestration potential of ecosystems and restore degraded ecosystems (Yao et al., 2018), which has been extensively concerned and used by countries all over the world ( Leigh \& Holgate, 1979; 
84 Gebregergs et al., 2019). For example, several forest enclosure trials have reported that forest 85 enclosure could increase the diversity and density of saplings and seedlings, quantity of natural herb, understory vegetation, as well as the cover of litters (Cabin et al., 2000; Miller \& Wells, 2003; Dodd \& Power, 2007), and decrease soil compaction and erosion (Spooner et al., 2002; Michels et al., 2012), subsequently increasing the soil organic $\mathrm{C}$ and $\mathrm{N}$ derived from litter decomposition and root exudation (Bai et al., 2012; Wu et al., 2014), facilitating forest establishment (Speed et al., 2014). Similarly, the results in the hillside forests of Uruguay indicated that exclusion of livestock with fence from the forest preferably boost soil conditions and provide opportunities for the regeneration of certain species (Etchebarne \& Brazeiro, 2016). However, other experiments found that fenced forests did not reveal evidence of tree regeneration or soil structure improvement (Fischer et al., 2009; Sankey, 2012). Therefore, the effect of fences excluding livestock on forest are complexity and variability, and there are lacking adequate evidences, particular in terms of the impact of enclosures on microorganisms.

Soil microorganisms play pivotal roles in the decomposition of tree litter, and nutrient mineralization (Xu et al., 2008; Burton et al., 2010).Compared to soil physic-chemical properties and changes in aboveground vegetation, microbes are more dynamic and sensitive to any small variations in soil or environmental stress (Cruz-Paredes et al., 2017), which can generally be considered as early indicators of the human induced effects on soil condition changes and soil ecology (Honeker et al., 2017; Vinhal-Freitas et al., 2017; Yang et al., 2018). So far, intensive studies have concerned the effects of enclosure on soil on soil physical, chemical and biological properties (Song et al., 2005), as well as soil nematode community (Zhang et al., 2019). However, researches on the effects of afforestation with enclosure management measures on soil microorganisms are insufficient.

In China, the current 'Three North' Shelterbelt Development Program (TNSDP), started in 1978, is the largest afforestation project in China and even worldwide (Li et al., 2012). Pinus sylvestris var. mongolica naturally distributed in Honghuaerji, as the main afforestation tree species, was first introduced to Zhanggutai, Liaoning Province, China (Zhou et al., 2019), which has been successfully promoted in more than 300 counties in 13 provinces and regions. According to the results of the eighth forest resource inventory (2009-2013), the area of Pinus sylvestris var. mongolica plantation has reached $4.17 \times 10^{5}$ ha, which has made important contribution to ecosystem service functions. However, due to the extensive grazing and litter removal in the Pinus 
115 sylvestris var. mongolica (PSM) plantations, the surface loses the litter layer that maintains the 116 moisture and ecosystem material circulation, resulting in severe soil degradation (Willcock et al., 117 2016), which has become a bottleneck and difficult problem to constraint the sustainable 118 development of plantations. About the enclosure of Pinus sylvestris var. mongolica, the study from 119 Zhang et al. (2012) suggested that the thickness and weight of litters of Pinus sylvestris var. mongolica in Zhanggutai area at the southern margin of Horqin sandy land increased significantly with the increase of the enclosure years. However, none of studies measured, in detail, particularly the effect of afforestation with Pinus sylvestris var. mongolica plantations combined with enclosure management (PSME) on soil microbial communities. In addition, the vegetation type was Arachis hypogaea (peanut) farmland prior to afforestation, and Arachis hypogaea (AH) were selected as the control. Thus, in present study, we investigated the responses of soil characteristics and microbial communities to afforestation with Pinus sylvestris var. mongolica plantations combined with enclosure management in Zhanggutai using the High-throughput sequencing technology. On the basis of former studies, we put three assumptions (i) PSM and PSME contribute to better increase soil nutrient accumulation compared to AH, especially PSME; (ii) PSM and PSME could clearly shift soil microbial communities compared with AH; (iii) Furthermore, soil microbial communities existed clear differences between PSME and PSM; (iv) PSM and PSME potentially regulate microbial properties through shifting the soil properties. This research could provide a new insight into the effects of enclosure on Pinus sylvestris and supply theoretical support for enclosure management of Pinus sylvestris.

\section{Materials and Methods}

Site information

The study area was located in Zhanggutai $\left(42^{\circ} 37^{\prime} 30^{\prime \prime}-42^{\circ} 50^{\prime} 00^{\prime \prime} \mathrm{N}, 122^{\circ} 11^{\prime} 15^{\prime \prime}-122^{\circ} 30^{\prime} 00^{\prime \prime} \mathrm{E}\right)$, north of Zhangwu county, northwest edge of Liaoning Province, China, which belongs to the north temperate continental monsoon climate with four distinct seasons, rain and heat in the same season, sufficient sunshine, large temperature difference between day and night. The annual average temperature is $5.7{ }^{\circ} \mathrm{C}$ with the highest of $35.2{ }^{\circ} \mathrm{C}$, and the lowest of $-29.5{ }^{\circ} \mathrm{C}$. The annual precipitation is $450-550 \mathrm{~mm}$, and annual evaporation of $1200-1450 \mathrm{~mm}$. The average elevation is $226.5 \mathrm{~m}$. The strong wind frequently occurred in spring and winter, and the instantaneous maximum wind speed is $32 \mathrm{~m} / \mathrm{s}$. And the sandstorms blows up to more than 240 times with speed 
146 Cambic Arenosols of sandy origin (FAO, 2006) with characteristic of coarse texture and loose

147 structure (Li et al., 2012).

148 Determination of vegetation type and soil samples collection

149 Four 1 ha sites of Pinus sylvestris var. mongolica plantations planted in 1986 with same site 150 conditions in Zhanggutai $\left(42^{\circ} 40^{\prime} 01^{\prime \prime} \mathrm{N}, 122^{\circ} 29^{\prime} 55^{\prime \prime} \mathrm{E} ; 42^{\circ} 39^{\prime} 49^{\prime \prime} \mathrm{N}, 122^{\circ} 30^{\prime} 00^{\prime \prime} \mathrm{E} ; 42^{\circ} 40^{\prime} 02^{\prime \prime} \mathrm{N}\right.$, $\left.1511^{\circ} 2^{\circ} 29^{\prime} 40^{\prime \prime} \mathrm{E} ; 42^{\circ} 42^{\prime} 39^{\prime \prime} \mathrm{N}, 122^{\circ} 28^{\prime} 49^{\prime \prime} \mathrm{E}\right)$ were selected. The extensive grazing and litter removal 152 in the Pinus sylvestris var. mongolica plantations were always existed. In order to promote the 153 sustainable development of Pinus sylvestris var. mongolica plantations, one permanent enclosure 154 plot with $50 \mathrm{~m} \times 50 \mathrm{~m}$ was established in each site in July, 2009. The same degree of disturbance 155 existed outside the enclosure in four sites, and plot of $50 \mathrm{~m} \times 50 \mathrm{~m}$ was randomly built up in each disturbance site. Prior to afforestation, the vegetation type was Arachis hypogaea (peanut) farmland, thus, we selected adjacent Arachis hypogaea with $50 \mathrm{~m} \times 50 \mathrm{~m}$ as the control. After removing the litter layer, soil samples were collected from 8 to 12 core points for each plot with using a soil auger of $2.5 \mathrm{~cm}$ in diameter and $0-10 \mathrm{~cm}$ of the depth and mixed as a composite soil sample, giving a total 12 soil samples. All soil samples were placed in an ice box, taken back to the laboratory, and roots and other debris were removed and discarded. These soil samples were divided into two parts, and one part for the determination of soil microbial communities was sieved through a $2-\mathrm{mm}$ screen and stored $-80^{\circ} \mathrm{C}$ immediately. While, another part for the determination of soil characteristics was air-dried at room temperature. Simultaneously the measurements of vegetation were completed in July 2019 (Table 1). In each plot, the diameter at breast height (DBH) and tree height were measured using a breast diameter ruler and a clinometer for all trees, respectively. Five $1 \times 1 \mathrm{~m}^{2}$ quadrat were randomly established in each plot and sampled for both accumulated litter and understory plant biomass.

\section{The determination of soil properties}

The soil $\mathrm{pH}$ was determined in a 1:2.5 soil-water suspension using a $\mathrm{pH}$ meter (MT-5000, Shanghai) with a glass electrode. The concentrations of total carbon (C) and total nitrogen (N) were assessed via an elemental analyzer (Euro Vector EA3000) with air-dried soil passed through a $0.2-\mathrm{mm}$ screen. Total phosphorus $(\mathrm{P})$ concentration was estimated with sulfuric acid-soluble perchlorate acid-molybdenum antimony colorimetric method. The alkali-hydrolysis and diffusion method was used to measure soil available $\mathrm{N}$ content. And the available $\mathrm{P}$ was extracted by $\mathrm{NaHCO}_{3}\left(0.5 \mathrm{~mol} \cdot \mathrm{L}^{-1}\right)$ and measured using the antimony molybdenum anti-colorimetric method. 


\section{Soil DNA extraction and amplification sequencing}

178 The DNA of samples was extracted from $0.5 \mathrm{~g}$ of soil with the FastDNA SPIN Kit for Soil (MP

179 Biomedicals, Santa Ana, CA, USA), according to the manufacturer's instructions. The genomic 180 DNA was amplified by PCR using the $16 \mathrm{~S}$ rRNA gene V3-V4 hypervariable regions region 181 primers (338F and $806 \mathrm{R}$ ) (Xu et al., 2016), and the Internal Transcribed Spacer (ITS) gene regions 182 primers (ITS1F-ITS2) (Caban et al., 2018; Nottingham et al., 2018). PCR reactions: $8.75 \mu$ of 183

$\mathrm{ddH}_{2} \mathrm{O} ; 5 \mu \mathrm{l}$ of Q5 reaction buffer (5×) and Q5 High-Fidelity GC buffer (5×), respectively; $2 \mu 1$ of dNTPs $(2.5 \mathrm{mM})$ and DNA Template, respectively; $1 \mu \mathrm{l}(10 \mathrm{uM})$ of forward primer and reverse primer, respectively; $0.25 \mu \mathrm{l}(5 \mathrm{U} / \mu \mathrm{l})$ of Q5 High-Fidelity DNA Polymerase, a total of $25 \mu \mathrm{l}$ mixture. PCR thermal cycling condition: an initial denaturation step at $98{ }^{\circ} \mathrm{C}$ for 5 min, then 25 cycles (denaturation at $98^{\circ} \mathrm{C}$ for $15 \mathrm{~s}$, annealing at $55^{\circ} \mathrm{C}$ for $30 \mathrm{~s}$, and elongation at $72{ }^{\circ} \mathrm{C}$ for 30 s), with final elongation step of $72{ }^{\circ} \mathrm{C}$ for $5 \mathrm{~min}$. Agencourt AMPure Beads (Beckman Coulter, Indianapolis, IN) and PicoGreen dsDNA Assay Kit (Invitrogen, Carlsbad, CA, USA) were used to purify and quantify PCR amplicons. Finally, the Illumina's MiSeq PE300 platform (Shanghai Personal Biotechnology Co., Ltd, Shanghai, China) was used for sequencing. The raw highthroughput sequencing data of bacteria and fungi were stored in the NCBI database with the accession number SRA accession of PRJNA562091 and PRJNA562096, respectively.

\section{Statistical Analyses}

The differences of soil characteristics and microbial community diversity under different treatments were performed as means $(n=4) \pm$ standard errors $(\mathrm{SE})$, and analyzed using one-way ANOVA with the least-significant-difference (LSD) test. The relationships between soil microbial diversity and chemical properties were explored using Spearman's rank correlation and visualized using R with the package of "corrplot". The shared and unique OTUs among different treatments were calculated and visualized using the packages of "venndiagram" in R. Non-metric multidimensional scaling (NMDS) analysis based on unweighted uniFrac and weighted unifrac distance matrix was used to investigate the distribution characteristics and the dissimilarity of soil bacterial and fungal communities among sites using R with the package of "vegan", respectively. Based on Bray-Curtis distance matrix, heatmap plots of soil bacteria and fungi with the relative abundances of top 50 were performed using $\mathrm{R}$ with the package of "vegan". Redundancy analysis (RDA) was further conducted to determine the relationships between soil chemical properties and soil microbial community structure using R with the packages of "vegan" and "car". Variance 
208 Partitioning Analysis (VPA) was used to quantitatively assess the contribution of each

209 environmental factor to the microbial communities using R with with the package of "vegan". 210 Associated network analysis was used to calculate the correlation between soil characteristics and 211 soil dominant bacterial and fungal phyla and visualized in Gephi.

\section{Results}

\section{Soil properties among different treatments}

214 Soil pH in this region exhibited acid soil, and the maximum value occurred in Pinus sylvestris var. mongolica (PSM) with 5.95, and distinctly higher than that of Arachis hypogaea (AH) and Pinus sylvestris var. mongolica combined with enclosure (PSME) $(P<0.01)$ (Table 2). Significant differences were observed in total $\mathrm{C}(\mathrm{F}=80.45, P<0.00)$, total N $(\mathrm{F}=31.22, P<0.00)$, total P $(\mathrm{F}$

$218=7.59, P=0.01)$, available $\mathrm{P}(\mathrm{F}=6.42, P=0.02)$ and available $\mathrm{N}(\mathrm{F}=4.68, P=0.04)$ among $\mathrm{AH}$, PSM and PSME. The values of soil total $\mathrm{C}$, total $\mathrm{N}$, and available $\mathrm{N}$ in $\mathrm{AH}$ exhibited the lowest with $3.96 \mathrm{~g} \cdot \mathrm{kg}^{-1}, 0.57 \mathrm{~g} \cdot \mathrm{kg}^{-1}$, and $35.39 \mathrm{mg} \cdot \mathrm{kg}^{-1}$, respectively. Site PSME could remarkably increase soil total $\mathrm{C}$, total $\mathrm{N}$, total $\mathrm{P}$, which were $1.34,1.25$, and 1.21 folds in compared to site PSM. Similarly, the available N concentration in PSME was 1.06 times than this of PSM. While, the value of soil available P were $20.9 \%$ higher in site PSM relative to the PSME land (Table 2).

\section{4}

\section{Soil microbial community diversity among different treatments}

A total of 582,908 bacterial valid sequences and 608,220 fungal effective sequences were acquired, with an average of 48,575 and 50,685, respectively, which were clustered into 6,443 OTUs and 1,257 OTUs according to the $97 \%$ similarity threshold. Rarefaction curves based on $97 \%$ similarity level tended to be flat with the increase of 16S rDNA and ITS rDNA sequences, suggesting that the number of sequences was enough and reasonable (Fig. S1). Bacterial OTUs identified in AH, PSM and PSME were 3,663, 4,821, and 4,603, with shared OTUs of 2,176 and unique OTUs of 753, 677, and 545, respectively (Fig. 1A). Fungal OTUs identified in AH, PSM and PSME were 502, 736, and 783, with shared OTUs of 166 and unique OTUs of 225, 197, and 237, respectively (Fig. 1B). The NMDS plot of bacterial OTUs indicated that soil bacterial communities among AH, PSM and PSME existed significant difference (stress=0.02), and microbial community assemblage in the AH remarkably differed compared with the PSM and PSME (Fig. 2A). For PSM and PSME, the soil bacterial communities existed some overlapping, manifesting that the soil bacterial community were similar (Fig. 2A). Similar patterns were found in soil fungal communities (stress $=0.01$ ), however, soil fungal communities from PSM and PSME exhibited no overlapping 
239 (Fig. 2B). Thus it can be seen afforestation with Pinus sylvestris var. mongolica could change soil 240 microbial communities, and the effects of Pinus sylvestris var. mongolica with enclosure on soil 241 fungal communities were significantly greater than those of bacterial communities (Fig. 2).

242 Indicators of bacterial community diversity, including Simpson index and Shannon index, 243 displayed no obvious differences among AH, PSM and PSME. Similar patterns were observed in 244 the fungal Simpson index and Shannon index (Table 3). The bacterial Chaol index and ACE index 245 in PSME were the highest with 3061.60 and 3082.46, respectively, followed by PSM and AH, no 246 significant differences compared to PSM $(P>0.05)$. Additionally, fungal Chao 1 index and ACE 247 index showed a similar trend with the maximum values in PSME of 413.35 and 419.45, 248 respectively (Table 3). The relationships between soil microbial community diversity and soil 249 characteristics were calculated with Spearman's rank correlation (Fig. 3). Soil bacterial Chao1 250 index and ACE index showed significantly positive correlations with total C, total N, available $\mathrm{N}$ 251 and $\mathrm{C} / \mathrm{N}$ (Fig. 3A). With regard to soil fungal community diversity, soil fungal Chaol index and 252 ACE index had significantly positive relations with soil total C, total N, and available N (Fig. 3B). 253 Accordingly, soil total $\mathrm{C}$, total $\mathrm{N}$ and available $\mathrm{N}$ were the main factors effecting the soil microbial 254 diversity (Fig. 3).

\section{Soil microbial community composition among different samples}

256 In case of soil bacteria, the dominant bacterial communities with the relative abundances great 257 than $1 \%$ were Actinobacteria (35.42\% - 43.37\%), Proteobacteria (21.95\% - 25.84\%), 258 Acidobacteria (5.61\% - 19.99\%), Chloroflexi (7.68\% - 12.55\%), WPS-2 (1.77\% - 4.13\%), 259 Gemmatimonadetes (2.00\% - 3.09\%), Patescibacteria (2.03\% - 2.55\%), Planctomycetes $(2.02 \%$ 260 2.37\%), Bacteroidetes (1.44\% - 2.06\%), and Firmicutes (0.78\% - 1.35\%), accounting for 97.74\%, 97.38\% and 98.30\% in AH, PSM, and PSME (Fig. 4A). No significant differences were observed in Proteobacteria, WPS-2, Patescibacteria, Planctomycetes, Bacteroidetes, and Firmicutes $(P>$ 0.05). Significant changes in the relative abundances of Actinobacteria $(\mathrm{F}=13.146, P=0.0021)$, Acidobacteria $(\mathrm{F}=87.849, P=0.0001)$, and Gemmatimonadetes $(\mathrm{F}=9.885, P=0.0054)$ were observed with the different samples. Specifically, PSM obviously increased the relative abundance of Acidobacteria, and decreased the relative abundance of Actinobacteria compared to AH $(P<$ 0.05). We further found that PSME could increase the Actinobacteria, and Gemmatimonadetes with the relative abundance of $43.37 \%$ and $2.33 \%$, while, which decreased the Acidobacteria and 
270 fungi, the dominant fungal communities were Ascomycota, Basidiomycota, and 271 Mortierellomycota, accounting for 86.49\%, 97.47\%, and 97.67\% in AH, PSM, PSME (Fig. 4B).

272 Compared to AH, PSM dramatically decreased Ascomycota and increased Basidiomycota $(P<$ 273 0.05). PSME could significantly increase Ascomycota, Mortierellomycota, and decrease the 274 relative abundance of Basidiomycota $(P<0.05)$ (Fig. 4B).

275

276

At the genus level, soil bacterial genera with the relative abundances greater than $1 \%$ were Crossiella, Jatrophihabitans, Conexibacter, Sphingomonas, Blastococcus, Acinetobacter, 277 Bradyrhizobium, RB41, Mycobacterium, Candidatus-Solibacter, Nocardioides, Gemmatimonas, and Bryobacter (Fig. 5A) among AH, PSM and PSME. PSME site improved the relative abundance of Crossiella, and decreased the relative abundance of Sphingomonas compared to PSM (Fig. 5A). The soil fungal genera with relative abundances greater than $1 \%$ were Penicillium, Mortierella, Amphinema, Trechispora, Pseudogymnoascus, Lectera, Didymella, Wilcoxina, Papiliotrema, and Talaromyces among AH, PSM and PSME (Fig. 5B). Amphinema and Wilcoxina were only existed in PSM and PSME, which are very common ectomycorrhizal fungi (Fig. 5B). On this view, afforestation with Pinus sylvestris could increase the relative abundances of soil ectomycorrhizal fungi. What's more, PSME site improved the relative abundances of Penicillium, Mortierella, Amphinema, Trechispora, and Pseudogymnoascus, and reduced the relative abundances of Trechispora and Wilcoxina relative to PSM (Fig. 5B). The heatmap plots of soil bacterial and fungal communities among different samples were divided into two clusters, including $\mathrm{AH}$, and PSM plus PSME, respectively, indicating that afforestation with Pinus sylvestris var. mongolica might remarkably shift soil microbial communities and the microbial communities between PSM and PSME were similar but also clearly different (Fig. 6).

The correlations between soil microbial community composition and soil environment

293

294

295

296

297

298

299

300

\section{factors}

RDA between soil bacterial OTUs great than 1 and soil characteristics indicated that the first two principal components explained approximately $54.84 \%$ and $25.22 \%$ of the total variability, respectively (Fig. 7A). Soil total C $(r=0.92)$, total $\mathrm{N}(\mathrm{r}=0.87), \mathrm{C} / \mathrm{N}(\mathrm{r}=0.91)$, available $\mathrm{P}(\mathrm{r}=$ $0.72)$ and available $\mathrm{N}(\mathrm{r}=-0.68)$ had lager contributions to RDA1. While, soil $\mathrm{pH}(\mathrm{r}=0.83)$ and total P $(r=-0.82)$ showed great relations with RDA2. The proportion of explanation of each soil constraint factors to microbial community were analyzed based on VPA. Soil $\mathrm{pH}$, total $\mathrm{C}$, total $\mathrm{N}$, $\mathrm{C} / \mathrm{N}$, total $\mathrm{P}$, available $\mathrm{P}$, and available $\mathrm{N}$ alone explained $2.60 \%, 4.39 \%, 4.74 \%, 2.50 \%, 7.95 \%$, 
301

302

303

304

305

306

307

308

309

310

311

312

313

314

315

316

317

318

319

320

321

322

323

324

325

326

327

328

329

$4.64 \%, 3.10 \%$ of the total variables (Table 4). The bacterial communities in AH formed individual cluster, however, bacterial communities from PSM and PSME existed some overlapping, indicating that soil bacterial community between PSM and PSME were more similar (Fig. 7A). Overtly, the bacterial communities of $\mathrm{AH}$ were strongly related to higher soil available P. In contrast, the contents of soil total $\mathrm{C}$, total $\mathrm{N}$, available $\mathrm{N}$ and $\mathrm{C} / \mathrm{N}$ did not correlate with the single cluster of AH (Fig. 7A).

In case of soil fungi, the CCA1 and CCA2 captured $34.91 \%$ and $16.99 \%$ of the total variations, and revealed that the fungal OTUs were divided into three distinctly different cluster groups, including AH, PSM, and PSME, respectively (Fig. 7B). Furthermore, soil total C (r = $0.86)$, total $\mathrm{N}(\mathrm{r}=0.79), \mathrm{C} / \mathrm{N}(\mathrm{r}=0.95)$, available $\mathrm{P}(\mathrm{r}=-0.75)$ and available $\mathrm{N}(\mathrm{r}=-0.71)$ made a great contribution to $\mathrm{CCA} 1$. And soil $\mathrm{pH}(\mathrm{r}=-0.79)$ and total $\mathrm{P}(\mathrm{r}=-0.67)$ had a large proportion to the CCA2 (Fig. 7B). Apparently, the fungal communities of AH were intensively linked to higher soil available $\mathrm{P}$, and the fungal communities of PSM were strongly related to higher soil pH value (Fig. 7B). Furthermore, soil pH, total C, total N, C/N, total P, available P, and available $\mathrm{N}$ alone explained $9.20 \%, 7.94 \%, 7.81 \%, 8.21 \%, 7.33 \%, 6.56 \%, 5.56 \%$ of the total variables (Table 4).

In terms of soil dominant bacterial and fungal phyla, we observed that the relative abundance of Actinobacteria existed significantly negative correlation with soil $\mathrm{pH}(\mathrm{r}=-0.73, P=0.01)$. While, the relative abundance of Actinobacteria dramatically increased with the increase of soil total $\mathrm{P}$ content $(\mathrm{r}=0.82, P=0.01)$. The relative abundance of Chloroflexi had significantly negative correlation with $\mathrm{C} / \mathrm{N}(\mathrm{r}=-0.78, P=0.01)$, while, which had dramatically positive relation with soil total $\mathrm{P}(\mathrm{r}=0.90, P=0.01)$. The relative abundance of Acidobacteria increased with the increase of soil available $\mathrm{N}(\mathrm{r}=0.79, P=0.01)$ and $\mathrm{C} / \mathrm{N}(\mathrm{r}=0.59, P=0.05)$. The relative abundance of Gemmatimonadetes increased with the increase of total $\mathrm{P}(\mathrm{r}=0.64, P=0.05)$ and available $\mathrm{P}(\mathrm{r}$ $=0.66, P=0.05)$ contents (Fig. 8). Ascomycota showed negative relation to available $\mathrm{N}(\mathrm{r}=-0.62$, $P=0.05)$. While, Basidiomycota existed significantly positive correlation with available $\mathrm{N}(\mathrm{r}=$ $0.62, P=0.05)$. Mortierellomycota exhibited significantly positive correlation with total $\mathrm{C}(\mathrm{r}=$ $0.62, P=0.05)$, total $\mathrm{N}(\mathrm{r}=0.61, P=0.05)$, and $\mathrm{C} / \mathrm{N}(\mathrm{r}=0.79, P=0.01)$, however, which showed negative relation to available $\mathrm{P}(\mathrm{r}=-0.74, P=0.01)$ (Fig. 8). 
330

331

332

333

334

335

336

337

338

339

340

341

342

343

344

345

346

347

348

349

350

351

352

353

354

355

356

357

358

359

360

\section{Discussion}

\section{Effects of afforestation combined with enclosure management on soil properties}

Afforestation is considered to be an effective option to sequester carbon in semi-arid regions (Nosetto et al., 2006). The improvement of soil fertility after restoration of vegetation is complex ecological processes, which is influenced by numerous biotic and abiotic factors (Cao et al., 2008). Our results also concluded that afforestation with Pinus sylvestris var. mongolica had positive influences on soil quality and significantly increased soil total $\mathrm{C}$ and total $\mathrm{N}$ concentrations compared to AH (Table 2), which was consistent with previous study (Li et al., 2012). Afforestation might facilitate the absorption of $\mathrm{C}$ through the accumulation of above-ground and underground biomass, and reduce the carbon loss through retarding the decomposition of soil organic matter and soil erosion (Nosetto et al., 2006). These results confirmed that afforestation with Pinus sylvestris var. mongolica in the Horqin Sandy Land was a positive and effective way to restore and increase soil $\mathrm{C}$ storage and improve soil quality in these semi-arid desertified lands (Li et al., 2012). In our study, soil PH was acid in this region with highest in PSM, and lowest in PSME, which was similar to the research from forests of Uruguay demonstrating that soil $\mathrm{pH}$ in excluded area was lower than in grazed area (Etchebarne \& Brazeiro, 2016). However, previous study from Inner Mongolia grasslands finding that soil $\mathrm{pH}$ increased and became more neutral with the increase of enclosure time (Ma et al., 2016). What's more, we further found that PSME could increase soil nutrients significantly than PSM, including soil total C, total N, total P and available $\mathrm{N}$ contents $(P<0.05)$, which was agreement with the studies about grassland from Xiong et al. (2016) and Gebregergs et al. (2019). The increase in total C and total $\mathrm{N}$ concentrations might be mainly ascribed to the undergrowth vegetation recovery, accumulation of litter and increase in soil nutrient return in PSME (Table 1), and changes in the "quality" and "quantity" of litter lay an important role in affecting the soil nutrient (Rajr et al., 2006). Identically, results of the impact of grazers on birch forest demonstrated that aboveground carbon stocks were higher in the long-term absence of sheep than in the continual presence of high sheep densities (Gebregergs et al., 2019). These results, as well as our findings, indicated that afforestation combined with enclosure management contribute to the accumulation of carbon stocks and the recovery of soil conditions in ecosystems in semi-arid regions (Grünzweig et al., 2003; Laclau, 2003; de Souza Oliveira Filho et al., 2019).

Effects of afforestation combined with enclosure management on soil microbial communities 
361 Soil microbes are an important part of soil nutrient cycling and transformation, affecting the 362 absorption and utilization of nutrients by plants. According to the results of the soil microbial 363 community diversity, vegetation restoration with Pinus sylvestris var. mongolica could clearly 364 increase the soil bacterial and fungal Chaol index and ACE index, as well as soil bacterial Shannon 365 index than AH (Table 3), which was consistent with past observation (Peng et al., 2017). The 366 development of plantations or enclosure management could change some soil microbes, thus 367 affecting soil community diversity through various pathways, such as species compatibility, cooperation, and competition among microorganisms (Yin et al., 2016). Plantation trees cover immediately influences the understory composition and available light quantity, which affects carbon distribution and the soil microbial community (Mitchell et al., 2012). In addition to this, long-term fertilization also adversely affects microbial populations (Sui et al., 2013). Additionally, PSME had increased soil Chaol index, ACE index of soil bacteria, and our observations agreed with the previous research that suggested fencing of degraded steppe significantly increased bacterial Chaol index, ACE index compared with free grazing (Zhou et al., 2012). However, PSME decreased soil bacterial Simpson index and Shannon index (Table 3), which was also similar with the report by Wang et al. (2019) who elaborated that free grazing site significantly decreased the bacterial diversity compared to enclosure site, particularly soil Shannon index. Beyond that, extensive studies have reported that moderate castration and grazing were more conducive to soil nutrient cycling than no grazing (Li et al., 2017; Liu et al., 2016), that likely contributed to the moderate pasture management can effectively stimulate functional microbial activity in the soil.

Soil bacterial and fungal community compositions significantly differed among AH, PSM, and PSME, and microbial community assemblage in the AH distinctly differed compared with the PSM and PSME (Fig. 2; Fig. 6; Fig. 7). Our these results were consistent with past observation suggesting that soil microbial communities exhibited clear differences between forest (poplar plantation) and agriculture land (Zea mays and Oryza sativa) (Cao et al., 2017). Not only that, 
387 PSME could change soil microbial communities, especially soil fungal communities (Fig. 2; Fig. 388 7), which was similar to findings from Patra et al. (2005) who emphasized that grazing induced 389 the changes of soil microbial size and composition. These results, as well as our findings, 390 elaborated that afforestation combined with enclosed management might influence the structures 391 of microbial communities to some extent. In addition, we found the dominant bacterial and fungal phyla among AH, PSM and PSME were nearly the same, although the relative abundances of them

393 were disparate. The predominant bacterial phylum was Actinobacteria (Fig. 4A), which was similar with findings of Liu et al. (2014) and Peng et al. (2017). While, our result was dissimilar to past survey demonstrating that Proteobacteria was the most abundant phylum (Urbanová et al., 2015). Actinobacteria is one of the main group of bacteria and play an important role in carbon cycling and organic matter turnover (Zheng et al., 2017), which predominate under stressful and harsh soil conditions (Teixeira et al., 2010). In our study, we found that Actinobacteria decreased markedly in PSM relative to AH, similar results were found in Zheng et al. (2017) who observed that relative abundance of Actinobacteria decreased markedly when croplands were converted to monoculture plantation. Interestingly, we further found that the relative abundances of Cyanobacteria and Chloroflexi increased in site PSM relative to PSME, which obtain energy and fix $\mathrm{CO}_{2}$ via photosynthesis (Klappenbach et al., 2004), and to a certain degree offset the reduction in plant carbon sequestration, which in turn enormously confirmed the observations of grassland (Yao et al., 2018). On the contrary, Nitrospirae decreased under PSM than PSME, agreement with observations of Yao et al. (2018) and Lücker et al. (2010). At the genus level, Crossiella, Jatrophihabitans, Conexibacter, and Sphingomonas were the dominant gerera (Fig. 5A), which was inconsistent with the observation demonstrating that Seudomonas and Acinetobacter were the dominant genera (Wang et al., 2019).

With regard to soil fungi, the dominant fungal communities were Ascomycota, Basidiomycota and Mortierellomycota (Fig. 4B). Basidiomycota and Ascomycota are the main decomposers of soil fungi, accounting for more than $90 \%$ of the total number of total fungal phyla 
413 (Vandenkoornhuyse et al., 2002; Bastian et al., 2009). To the best of our knowledge, 414 Basidiomycota play vital roles in regulating the decomposition of low quality lignification and 415 aromatic substrates (Six et al., 2006). Our results demonstrated that the relative abundances of 416 Basidiomycota in PSM and PSME were higher than in AH, which confirmed that the relative 417 abundance of Basidiomycota gradually accumulate with the increases of the undergrowth 418 vegetation diversity, tree cover and litter content (Toljander et al., 2006). This finding explored 419 why pine forest soils with higher $\mathrm{C} / \mathrm{N}$ than agriculture land harbored a high prevalence of 420 Basidiomycota. Interestingly, afforestation with Pinus sylvestris var. mongolica could signally 421 increase soil ectomycorrhizal fungus, such as Amphinema and Wilcoxina (Fig. 5B). What's more, 422 PSME site improved the relative abundance of Amphinema, and reduced the relative abundances 423 of Wilcoxina relative to PSM (Fig. 5B). Amphinema plays an important role in plant nutrient 424 absorption, which is known as widespread ECM species and efficient root colonizers (Kranabetter 425 2004; Menkis et al. 2011; Vaario et al. 2009). Wilcoxina belongs to Ascomycetous ECM fungi 426 (Lazarević \& Menkis, 2018), which have been commonly reported in association with conifer 427 seedlings, (Menkis et al., 2005). It is speculated that intensive agriculture, afforestation combined 428 with enclosed management could greatly influence the diversity and structure of the soil microbial communities.

430

431

432

433

434

435

436

\section{The correlations between soil variations and microbial community composition}

Increasing evidence indicates that environmental conditions are key factors in shaping the structures of microbial communities (Hanson et al., 2012). The biogeochemical processes of terrestrial ecosystems are significantly affected by afforestation (Deng et al., 2016), which could alter soil properties (C, N, P) and their ecological stoichiometry (Ren et al., 2016), thus affecting the structure and function of soil microbial communities (Lauber et al., 2013). In our study, soil bacterial Chaol index and ACE index showed significantly positive correlation with total C, total $\mathrm{N}$, and available $\mathrm{N}$ and obviously positive relationship with $\mathrm{C} / \mathrm{N}$ (Fig. 3A), in line with previous observations ( $\mathrm{Li}$ et al., 2014). In present study, the soil microbial community structure were affected by multiple environmental factors (Fig. 7), which was similar to other results (Griffiths et al., 2011; Deng et al., 2020). RDA plots illustrated that changes in bacterial community structure 
441 were associated soil $\mathrm{pH}, \mathrm{C} / \mathrm{N}$, total $\mathrm{C}$, total $\mathrm{P}$, total $\mathrm{N}$, available $\mathrm{N}$, and available $\mathrm{P}$ (Fig. 7A), which 442 was accordance with the results from Chao et al. (2016) and Santonja et al. (2018) who reported 443 that soil nutrients (total $\mathrm{C}$, total $\mathrm{N}$, total $\mathrm{P}$ and available $\mathrm{P}$ ) were the main factors influencing the 444 bacterial communities, similar observations were observed (Zornoza et al., 2015; Zeng et al., 2016; 445 Li et al., 2017). Soil organic carbon also influenced soil Actinobacteria and Acidobacteria 446 abundances, as previous research have reported that Acidobacteria are more abundant in soil with 447 relatively high soil organic carbon, and low organic carbon soil consistently exhibits the highest 448 abundance of Actinobacteria (Sul et al., 2013). These were inconsistent with our observations that 449 the relative abundance of Actinobacteria were negatively correlated with $\mathrm{pH}$ and positively related 450 with soil total P (Fig. 8). Previous study found that the relative abundances of Acidobacteria were 451 positively correlated with soil pH (6.67-9.01) (Yao et al., 2016). However, no similar results were 452 found in our study, possibly because the soil pH range in our study was relatively small (5.61 453 5.95) (Table 2).

454 In case of soil fungal community structure, CCA plot suggested that soil $\mathrm{pH}$, total C, total $\mathrm{N}$, $455 \mathrm{C} / \mathrm{N}$, total $\mathrm{P}$, available $\mathrm{N}$, available $\mathrm{P}$ were the dominant driving factors (Fig. 8), which was similar 456 with the results obtained in the previous studies (Lauber et al., 2008; Yang et al., 2013; Deng et 457 al., 2019). Basidiomycota existed significantly positive correlation with available N, similar results 458 were obtained in Chinese pine plantations on the Loess Plateau (Dang et al., 2017). While, 459 Ascomycota showed negative relation to available $\mathrm{N}$, which was inconsistent with past study 460 demonstrating that soil phosphorous is considered an important regulator of Ascomycota in the 461 soil (Lauber et al., 2013). The results illustrated that afforestation combined with enclosed 462 management potentially regulate microbial properties through shifting the soil properties.

\section{Conclusions}

464 In summary, our data demonstrated that there were obviously differences in soil chemical 465 parameters and soil microbial communities among different samples. Afforestation with Pinus 466 sylvestris var. mongolica had positive influences on soil quality and significantly increased soil 467 total $\mathrm{C}$ and total $\mathrm{N}$ concentrations compared to $\mathrm{AH}$. Our results confirmed that the enclosure with 468 Pinus sylvestris var. mongolica was a positive way to restore and improve soil quality in these 469 semi-arid desertified lands. Vegetation restoration with Pinus sylvestris var. mongolica could 470 clearly increase the soil bacterial community diversity and fungal Chaol index and ACE index. 471 Additionally, enclosure of Pinus sylvestris var. mongolica could further increase soil Chao1 index, 
472 ACE index of soil bacteria. Soil total $\mathrm{C}$, total $\mathrm{N}$, and available $\mathrm{N}$ concentrations in this area were

473 the main factors affecting the soil microbial community diversity. Afforestation with Pinus 474 sylvestris var. mongolica might remarkably shift soil microbial communities, and the microbial 475 communities between PSM and PSME were similar but also clearly different. The effects of PSME 476 on soil fungal communities were significantly greater than those of bacterial communities. What's 477 more, the soil microbial community structure were affected by multiple environmental factors, and 478 changes in soil chemical parameters induced by afforestation and enclosed management 479 potentially regulated microbial properties. This study provides deep insights into the effects of 480 afforestation with Pinus sylvestris var. mongolica combined enclosure management on soil 481 microbial communities in Zhanggutai and Horqin sand ecosystems.

482

483

484

485

\section{References}

Bai YF, Wu JG, Clark CM, Pan QM, Zhang LX, Chen SP, Wang QB, Han XG. 2012. Grazing alters ecosystem functioning and $\mathrm{C}: \mathrm{N}: \mathrm{P}$ stoichiometry of grasslands along a regional precipitation gradient. Journal of Applied Ecology 49(6): 1204-1215 DOI 10.1111/j.1365-2664.2012.02205.x.

Bastian F, Bouziri L, Nicolardot B, Ranjard L. 2009. Impact of wheat straw decomposition on successional patterns of soil microbial community structure. Soil Biology and Biochemistry 41(2): 262-275 DOI 10.1016/j.soilbio.2008.10.024.

Belsky AJ, Blumenthal DM. 1997. Effects of livestock grazing on stand dynamics and soils in upland forests of the interior west. Conservation Biology 11(2): 315-327 DOI 10.1046/j.15231739.1997.95405.x.

Burton J, Chen C, Xu ZH, Ghadiri H. 2010. Soil microbial biomass, activity and community composition in adjacent native and plantation forests of subtropical Australia. Journal of Soils and Sediments 10(7): 1267-1277 DOI 10.1007/s11368-010-0238-y.

Caban JR, Kuppusamy S, Kim JH, Yoon Y, Kim S, Lee SS. 2018. Green manure amendment enhances microbial activity and diversity in antibiotic-contaminated soil. Applied Soil Ecology 129: 72-76 DOI 10.1016/j.apsoil.2018.04.013.

Cabin RJ, Weller SG, Lorence DH, Flynn TW, Sakai AK, Sandquist D, Hadway LJ. 2000. Effects of long-term ungulate exclusion and recent alien species control on the preservation and restoration of a Hawaiian tropical dry forest. Conservation Biology 14(2): 439-453 DOI 10.1046/j.1523-1739.2000.99006.x. 
502

503

504

505

506

507

508

509

510

511

512

513

514

515

516

517

518

519

520

521

522

523

524

525

526

527

528

529

530

531

Cao CY, Jiang DM, Teng XH, Jiang Y, Liang WJ, Cui ZB. 2008. Soil chemical and microbiological properties along a chronosequence of Caragana microphylla Lam. plantations in the Horqin sandy land of Northeast China. Applied Soil Ecology 40(1): 78-85 DOI 10.1016/j.apsoil.2008.03.008.

Cao CY, Zhang Y, Qian W, Liang CP, Wang CM, Tao S. 2017. Land-use changes influence soil bacterial communities in a meadow grassland in Northeast China. Solid Earth 8(5): 1119-1129 DOI 10.5194/se-8-1119-2017.

Chao Y, Liu W, Chen Y, Chen W, Zhao L, Ding Q, Wang S, Tang YT, Zhang T, Qiu RL. 2016. Structure, variation, and co-occurrence of soil microbial communities in abandoned sites of a rare earth elements mine. Environmental Science and Technology 50(21): 11481-11490 DOI 10.1021/acs.est.6b02284.

Chen FS, Zeng DH, Fahey TJ, Liao PF. 2010. Organic carbon in soil physical fractions under different-aged plantations of Mongolian pine in semi-arid region of Northeast China. Applied Soil Ecology 44(1): 42-48 DOI 10.1016/j.apsoil.2009.09.003.

Chevasco ED, Minogue PJ, Mackowiak C, Comerford NB. 2016. Fertilization and pine straw raking in slash pine plantations: $P$ removals and effects on total and mobile soil, foliage and litter P pools. Forest Ecology and Management 376: 310-320 DOI 10.1016/j.foreco.2016.06.009.

Cruz-Paredes C, Wallander H, Kjøller R, Rousk J. 2017. Using community trait-distributions to assign microbial responses to $\mathrm{pH}$ changes and $\mathrm{Cd}$ in forest soils treated with wood ash. Soil Biology and Biochemistry 112: 153-164. DOI 10.1016/j.soilbio.2017.05.004.

D’Odorico P, Bhattachan A, Davis KF, Ravi S, Runyan CW. 2013. Global desertification: Drivers and feedbacks. Advances in Water Resources 51: 326-344. DOI 10.1016/j.advwatres.2012.01.013.

Dang P, Yu X, Le H, Liu J, Shen Z, Zhao Z. 2017. Effects of stand age and soil properties on soil bacterial and fungal community composition in Chinese pine plantations on the Loess Plateau. PloS One 12(10): e0186501 DOI 10.1371/journal.pone.0186501.

de Souza Oliveira Filho J, Vieira JN, da Silva EMR, de Oliveira JGB, Gervasio MP, Brasileiro FG. 2019. Assessing the effects of 17 years of grazing exclusion in degraded semi-arid soils: Evaluation of soil fertility, nutrients pools and stoichiometry. Journal of Arid Environments 166: 1-10 DOI 10.1016/j.jaridenv.2019.03.006. 
532

533

534

535

536

537

538

539

540

541

542

543

544

545

546

547

548

549

550

551

552

553

554

555

556

557

558

559

560

561

Deng JJ, Yin Y, Luo JY, Zhou YB, Zhu WX. 2019. Different revegetation types alter soil physical-chemical characteristics and fungal community in the Baishilazi Nature Reserve. PeerJ 6: e6251 DOI 10.7717/peerj.6251.

Deng JJ, Bai XJ, Zhou YB, Zhu WX, Yin Y. 2020. Variations of soil microbial communities accompanied by different vegetation restoration in an open-cut iron mining area. Science of The Total Environment 704: 135243. DOI 10.1016/j.scitotenv.2019.135243.

Deng Q, Cheng X, Hui D, Zhang Q, Li M, Zhang Q. 2016. Soil microbial community and its interaction with soil carbon and nitrogen dynamics following afforestation in central China. Science of the Total Environment 541: 230-237 DOI 10.1016/j.scitotenv.2015.09.080.

Dodd MB, Power IL. 2007. Recovery of Tawa-dominated forest fragments in the Rotorua Basin, New Zealand, after cessation of livestock grazing. Ecological Management and Restoration 8(3): 208-217 DOI 10.1111/j.1442-8903.2007.00369.x.

Etchebarne V, Brazeiro A. 2016. Effects of livestock exclusion in forests of Uruguay: Soil condition and tree regeneration. Forest Ecology and Management 362: 120-129 DOI 10.1016/j.foreco.2015.11.042.

FAO I. 2006. ISRIC: World reference base for soil resource in world soil resource report no. 103. FAO, Rome, Italy, 15.

Fischer J, Stott J, Zerger A, Warren, G, Sherren, K, Forresterc RI. 2009. Reversing a tree regeneration crisis in an endangered ecoregion. Proceedings of the National Academy of Sciences 106(25): 10386-10391 DOI 10.1073/pnas.0900110106.

Fleischner TL. 1994. Ecological costs of livestock grazing in western North America. Conservation Biology 8(3): 629-644 DOI 10.1046/j.1523-1739.1994.08030629.x.

Fox TR. 2000. Sustained productivity in intensively managed forest plantations. Forest Ecology and Management 138(1-3): 187-202 DOI 10.1016/S0378-1127(00)00396-0.

Gao Y, Qiu GY, Shimizu H, Tobe K, Sun B, Wang J. 2002. A 10-Year study on techniques for vegetation restoration in a desertified Salt Lake area. Journal of Arid Environments 52(4): 483497 DOI 10.1006/jare.2002.1013.

Gebregergs T, Tessema ZK, Solomon N, Birhane E. 2019. Carbon sequestration and soil restoration potential of grazing lands under exclosure management in a semi-arid environment of northern Ethiopia. Ecology and Evolution 9: 6468-6479 DOI 10.1002/ece3.5223. 
562

563

564

565

566

567

568

569

570

571

572

573

574

575

576

577

578

579

580

581

582

583

584

585

586

587

588

589

590

591

Griffiths RI, Thomson BC, James P, Bell T, Bailey M, Whiteley AS. 2011. The bacterial biogeography of British soils. Environmental Microbiology 13(6): 1642-1654 DOI 10.1111/j.1462-2920.2011.02480.x

Grünzweig JM, Lin TL, Rotenberg E, Schwartz A, Yakir D. 2003. Carbon sequestration in arid-land forest. Global Change Biology 9(5): 791-799 DOI 10.1046/j.1365-2486.2003.00612.x.

Haberl H, Erb KH, Krausmann F, Gaube V, Bondeau A, Plutzar C, Gingrich S, Lucht W, Fischer-Kowalski M. 2007. Quantifying and mapping the human appropriation of net primary production in earth's terrestrial ecosystems. Proceedings of the National Academy of Sciences 104(31): 12942-12947 DOI 10.1073/pnas.0704243104.

Hanson C.A, Fuhrman J.A, Hornerdevine MC, Martiny JB. 2012. Beyond biogeographic patterns: processes shaping the microbial landscape. Nature Reviews Microbiology 10(7): 497506. DOI 10.1038/nrmicro2795.

He C, Tian J, Gao B, Zhao Y. 2015. Differentiating climate-and human-induced drivers of grassland degradation in the Liao River Basin, China. Environ. Environmental Monitoring and Assessment 187(1): 4199. DOI 10.1007/s10661-014-4199-2.

Hofmeister J, Oulehle F, Krám P, Hruška J. 2008. Loss of nutrients due to litter raking compared to the effect of acidic deposition in two spruce stands, Czech Republic. Biogeochemistry 88(2): 139-151 DOI 10.1007/s10533-008-9201-z.

Honeker LK, Neilson JW, Root RA, Gil-Loaiza J, Chorover J, Maier RM. 2017. Bacterial rhizoplane colonization patterns of Buchloe dactyloides growing in metalliferous mine tailings reflect plant status and biogeochemical conditions. Microbial Ecology 74(4): 853-867 DOI 10.1007/s00248-017-0998-7.

Hu YL, Zeng DH, Fan ZP, Chen GS, Zhao Q, Pepper D. 2008. Changes in ecosystem carbon stocks following grassland afforestation of semiarid sandy soil in the southeastern Keerqin Sandy Lands, China. Journal of Arid Environments 72(12): 2193-2200 DOI 10.1016/j.jaridenv.2008.07.007.

Klappenbach JA, Pierson BK. 2004. Phylogenetic and physiological characterization of a filamentous anoxygenic photoautotrophic bacterium 'Candidatus Chlorothrix halophila'gen. nov., sp. nov., recovered from hypersaline microbial mats. Archives of Microbiology 181(1): 17-25 DOI 10.1007/s00203-003-0615-7. 
592

593

594

595

596

597

598

599

600

601

602

603

604

605

606

607

608

609

610

611

612

613

614

615

616

617

618

619

620

621

Kranabetter JM. Ectomycorrhizal community effects on hybrid spruce seedling growth and nutrition in clearcuts. 2004. Canadian Journal of Botany 82(7): 983-991 DOI 10.1139/b04-077.

Laclau P. 2003. Biomass and carbon sequestration of ponderosa pine plantations and native cypress forests in northwest Patagonia. Forest Ecology and Management 180(1-3): 317-333 DOI 10.1016/S0378-1127(02)00580-7.

Lauber CL, Ramirez KS, Aanderud Z, Lennon J, Fierer N. 2013. Temporal variability in soil microbial communities across land-use types. The ISME Journal 7(8): 1641-1650 DOI 10.1038/ismej.2013.50.

Lauber CL, Strickland MS, Bradford MA, Fierer N. 2008. The influence of soil properties on the structure of bacterial and fungal communities across land-use types. Soil Biology and Biochemistry 40(9): 2407-2415 DOI 10.1016/j.soilbio.2008.05.021.

Leigh JH, Holgate MD. 1979. The responses of the understorey of forests and woodlands of the Southern Tablelands to grazing and burning. Australian Journal of Ecology 4(1): 25-45 DOI 10.1111/j.1442-9993.1979.tb01196.x.

Li H, Ye DD, Wang XG, Settles ML, Wang J, Hao ZQ, Zhou LS, Dong P, Jiang Y, Ma ZS. 2014. Soil bacterial communities of different natural forest types in Northeast China. Plant and Soil 383(1-2): 203-216 DOI 10.1007/s11104-014-2165-y.

Li J, Tong X, Awasthi MK, Wu FY, Ha S. Ma JY, Sun XH, He C. 2018. Dynamics of soil microbial biomass and enzyme activities along a chronosequence of desertified land revegetation. Ecological Engineering 111: 22-30 DOI 10.1016/j.ecoleng.2017.11.006.

Li J, Zhang Q, Li Y, Liu J, Pan H, Guan XM, Xu XY, Xu JM, Di HJ. 2017. Impact of mowing management on nitrogen mineralization rate and fungal and bacterial communities in a semiarid grassland ecosystem. Journal of Soils and Sediments 17(6): 1715-1726 DOI 10.1007/s11368-0161620-1.

Li MM, Liu A, Zou CJ, Xu WD. Shimizu H, Wang KY. 2012. An overview of the "ThreeNorth" Shelterbelt project in China. Forestry Studies in China 14(1): 70-79 DOI 10.1007/s11632012-0108-3.

Li XY, Sun J, Wang HH, Li X, Wang J, Zhang HW. 2017. Changes in the soil microbial phospholipid fatty acid profile with depth in three soil types of paddy fields in China. Geoderma 290: 69-74 DOI 10.1016/j.geoderma.2016.11.006. 
622

623

624

625

626

627

628

629

630

631

632

633

634

635

636

637

638

639

640

641

642

643

644

645

646

647

648

649

650

651

652

Li Y, Awada T, Zhou X, Shang W, Chen Y, Zuo X, Wang S, Liu X, Feng J. 2012. Mongolian pine plantations enhance soil physico-chemical properties and carbon and nitrogen capacities in semi-arid degraded sandy land in China. Applied Soil Ecology 56: 1-9 DOI 10.1016/j.apsoil.2012.01.007.

Lindquist EJ, D'Annunzio R, Gerrand A, MacDicken K. 2012. Global forest land-use change 1990-2005. Food and agriculture organization of the United Nations (FAO).

Liu J, Zhang Q, Li Y, Di, HJ, Xu JM, Li JY, Guan XM, Xu XY, Pan H. 2016. Effects of pasture management on soil fertility and microbial communities in the semi-arid grasslands of Inner Mongolia. Journal of Soils and Sediments 16(1): 235-242 DOI 10.1007/s11368-015-12107.

Liu JJ, Sui YY, Yu ZH, Shi Y, Chu HY, Jin J, Liu, XB, Wang GH. 2014. High throughput sequencing analysis of biogeographical distribution of bacterial communities in the black soils of northeast China. Soil Biology and Biochemistry 70: 113-122 DOI 10.1016/j.soilbio.2013.12.014.

Lücker S, Wagner M, Maixner F, Pelletier E, Koch H, Vacherie B, Rattei T, Damsté JS, Spieck E, Le Paslier D, Daims H. 2010. A nitrospira metagenome illuminates the physiology and evolution of globally important nitrite-oxidizing bacteria. Proceedings of the National Academy of Sciences 107(30): 13479-13484 DOI 10.2307/25708741.

Ma TL, Chen H, Wang YF, Kang XM, Tian JQ, Zhou XQ, Zhu Q, Peng CH, Liu LF, Hu J, Zhan W, Zhu EX. 2016. Effects of enclosure time on the community composition of methanotrophs in the soils of the Inner Mongolia grasslands. Journal of soils and sediments 16(3): 1022-1031 DOI 10.1007/s11368-015-1305-1.

Menkis A, Bakys R, Lygis V, Vasaitis R. 2011. Mycorrhization, establishment and growth of outplanted Picea abies seedlings produced under different cultivation systems. Silva Fennica 45(2): 283-289 DOI 10.14214/sf.118.

Menkis A, Vasiliauskas R, Taylor AFS, Stenlid J, Finlay R. 2005. Fungal communities in mycorrhizal roots of conifer seedlings in forest nurseries under different cultivation systems, assessed by morphotyping, direct sequencing and mycelial isolation. Mycorrhiza 16(1): 33-41 DOI 10.1007/s00572-005-0011-z.

Michels GH, Vieira EM, de Sá FN. 2012. Short-and long-term impacts of an introduced large herbivore (Buffalo, Bubalus bubalis L.) on a neotropical seasonal forest. European Journal of Forest Research 131(4): 965-976 DOI 10.1007/s10342-011-0568-3. 
Miller C, Wells A. 2003. Cattle grazing and the regeneration of totara (Podocarpus totara var. 654 waihoensis) on river terraces, south Westland, New Zealand. New Zealand Journal of Ecology 27:

655

656

657

658

659

660

661

662

663

664

665

666

667

668

669

670

671

672

673

674

675

676

677

678

679

680

681

\section{7-44 DOI 10.1520/STP11187S.}

Mitchell RJ, Keith AM, Potts JM, Ross JM, Reid E, Dawson LA. 2012. Overstory and understory vegetation interact to alter soil community composition and activity. Plant and Soil 352(1-2): 65-8 DOI 10.1007/s11104-011-0980-y.

Mu SJ, Zhou SX, Chen YZ, Li JL, Ju WM, Odeh IOA. 2013. Assessing the impact of restoration-induced land conversion and management alternatives on net primary productivity in Inner Mongolian grassland, China. Global and Planetary Change 108: 29-41 DOI 10.1016/j.gloplacha.2013.06.007.

Nosetto MD, Jobbágy EG, Paruelo JM. 2006. Carbon sequestration in semi-arid rangelands: Comparison of Pinus ponderosa plantations and grazing exclusion in NW Patagonia. Journal of Arid Environments 67(1): 142-156 DOI 10.1016/j.jaridenv.2005.12.008.

Nottingham AT, Fierer N, Turner BL, Whitaker J, Ostle NJ, McNamara NP, Bardgett RD, Leff JW, Salinas N, Silman MR, Kruuk LEB, Meir P. 2018. Microbes follow Humboldt: temperature drives plant and soil microbial diversity patterns from the Amazon to the Andes. Ecology 99(11): 2455-2466 DOI 10.1002/ecy.2482.

Nunezmir GC, Iannone BVI, Curtis K, Fei SL. 2015. Evaluating the evolution of forest restoration research in a changing world: a "big literature" review. New Forests 46(5-6): 669-682 DOI 10.1007/s11056-015-9503-7.

Patra AK, Abbadie L, Clays-Josserand A, Degrange V, Grayston SJ, Loiseau P, Louault F, Mahmood S, Nazaret S, Philippot L, Poly F, Prosser JI, Richaume A, Le Roux X. 2005. Effects of grazing on microbial functional groups involved in soil $\mathrm{N}$ dynamics. Ecological Monographs 75(1): 65-80 DOI 10.1890/03-0837.

Peng M, Jia H, Wang Q. 2017. The effect of land use on bacterial communities in saline-alkali soil. Current Microbiology 74(3): 325-333 DOI 10.1007/s00284-017-1195-0.

Rajr C, Currie WS, Townsend PA. 2006. Carbon sequestration and nutrient cycling implications of the evergreen understory layer in Appalachian forests. Forest Ecology and Management 231(1-3): 63-77 DOI 10.1016/j.foreco.2006.04.040.

Peer) reviewing PDF | (2019:10:42362:1:0:NEW 29 Jan 2020) 
682

683

684

685

686

687

688

689

690

691

692

693

694

695

696

697

698

699

700

701

702

703

704

705

706

707

708

709

710

711

712

Ren CJ, Zhao FZ, Kang D, Yang GH, Han XH, Tong XG, Feng YZ, Ren XG. 2016 Linkages of $\mathrm{C}: \mathrm{N}$ : $\mathrm{P}$ stoichiometry and bacterial community in soil following afforestation of former farmland. Forest Ecology and Management 376: 59-66. DOI 10.1016/j.foreco.2016.06.004.

Sankey TT. 2012. Woody-Herbaceous-Livestock Species Interaction//Ecotones between forest and grassland. Springer, New York NY 89-114 DOI 10.1007/978-1-4614-3797-0_4.

Santonja M, Foucault Q, Rancon A, Gauquelin T, Fernandez C, Baldy V, Mirleau P. 2018. Contrasting responses of bacterial and fungal communities to plant litter diversity in a Mediterranean oak forest. Soil Biology and Biochemistry 125: 27-36 DOI 10.1016/j.soilbio.2018.06.020.

Six J, Frey SD, Thiet RK, Batten KM. 2006. Bacterial and fungal contributions to carbon sequestration in agroecosystems. Soil Science Society of America Journal 70(2): 555-569 DOI 10.2136/sssaj2004.0347.

Song YZ, Li YL, Cui JY, Zhao WZ. 2005. Influences of continuous grazing and livestock exclusion on soil properties in a degraded sandy grassland, Inner Mongolia, northern China. Catena 59(3): 267-278 DOI 10.1016/j.catena.2004.09.001.

Speed JDM, Martinsen V, Mysterud A, Mulder J, Holand Ø, Austrheim G. 2014. Long-term increase in aboveground carbon stocks following exclusion of grazers and forest establishment in an alpine ecosystem. Ecosystems 17(7): 1138-1150 DOI 10.1007/s10021-014-9784-2.

Spooner P, Lunt I, Robinson W. 2002. Is fencing enough? The short-term effects of stock exclusion in remnant grassy woodlands in southern NSW. Ecological Management and Restoration 3(2): 117-126 DOI 10.1046/j.1442-8903.2002.00103.x.

Su YZ, Zhang TH, Li YL, Wang F. 2005. Changes in soil properties after establishment of Artemisia halodendron and Caragana microphylla on shifting sand dunes in semiarid Horqin Sandy Land, Northern China. Environmental Management 36(2): 272-281 DOI 10.1007/s00267004-4083-x.

Sui YY, Jiao XG, Liu XB, Zhang XY, Ding GW. 2013. Response of soil microbial biomass and enzyme activity to soil fertilization in an eroded farmland of Chinese Mollisols. Communications in Soil Science and Plant Analysis 44(19): 2809-2819 DOI 10.1080/00103624.2013.811525.

Sul WJ, Asuming-Brempong S, Wang Q, Tourlousse DM, Penton CR, Deng Y, Rodrigues JLM, Adiku SGK, Jones JW, Zhou JZ, Cole JR, Tiedje JM. 2013. Tropical agricultural land 
713 management influences on soil microbial communities through its effect on soil organic carbon.

714 Soil Biology and Biochemistry 65: 33-38 DOI 10.1016/j.soilbio.2013.05.007.

715 Teixeira LC, Peixoto RS, Cury JC, Sul WJ, Pellizari VH, Tiedje J, Rosado AS. 2010. Bacterial 716 diversity in rhizosphere soil from Antarctic vascular plants of Admiralty Bay, maritime Antarctica. 717 The ISME Journal 4(8): 989-1001 DOI 10.1038/ismej.2010.35.

718 Toljander JF, Eberhardt U, Toljander YK, Paul LR, Taylor AF. 2006. Species composition of 719 an ectomycorrhizal fungal community along a local nutrient gradient in a boreal forest. New 720 Phytologist 170(4): 873-883 DOI 10.1111/j.1469-8137.2006.01718.x.

721 Urbanová M, Šnajdr J, Baldrian P. 2015. Composition of fungal and bacterial communities in 722 forest litter and soil is largely determined by dominant trees. Soil Biology and Biochemistry 84: 723 53-64 DOI 10.1016/j.soilbio.2015.02.011.

724 Vandenkoornhuyse P, Baldauf SL, Leyval C, Straczek J, Young JP. 2002. Extensive fungal 725 diversity in plant roots. Science 295(5562): 2051-2051 DOI 10.1126/science.295.5562.2051.

726 Vargas GH, Velásquez LRS, Valdovinos TFC, López MRP, Guzmán RC. 2000. Efecto de la 727 ganadería extensiva sobre la regeneración arbórea de los bosques de la Sierra de Manantlán. 728 Madera y Bosques 6(2): 13-28.

729 Vaario LM, Tervonen A, Haukioja K, Haukioja M, Pennanen T, Timonen S. 2009. The effect 730 of nursery substrate and fertilization on the growth and ectomycorrhizal status of containerized 731 and outplanted seedlings of Picea abies. Canadian Journal of Forest Research 39(1): 64-75 DOI $73210.1139 / \mathrm{X} 08-156$.

733 Vinhal-Freitas IC, Corrêa GF, Wendling B, Bobulska L, Ferreira AS. 2017. Soil textural class 734 plays a major role in evaluating the effects of land use on soil quality indicators. Ecological 735 Indicators 74: 182-190 DOI 10.1016/j.ecolind.2016.11.020.

736 Wang HH, Li JY, Zhang QC, Liu J, Yi B, Li Y, Wang JW, Di HJ. 2019. Grazing and enclosure 737 alter the vertical distribution of organic nitrogen pools and bacterial communities in semiarid 738 grassland soils. Plant and Soil 493: 1-15 DOI 10.1007/s11104-019-04045-6.

739 Willcock S, Phillips OL, Platts PJ, Swetnam RD, Balmford A, Burgess ND, Ahrends A, 740 Bayliss J, Doggart N, Doody K, Fanning E, Green JM, Hall J, Howell KL, Lovett JC, Marchant 741 R, Marshall AR, Mbilinyi B, Munishi PK, Owen N, Topp-Jorgensen EJ, Lewis SL. 2016. Land 742 cover change and carbon emissions over 100 years in an African biodiversity hotspot. Global 743 Change Biology 22(8): 2787-2800 DOI 10.1111/gcb.13218. 
744

745

746

747

748

749

750

751

752

753

754

755

756

757

758

759

760

761

762

763

764

765

766

767

768

769

770

771

772

773

774

Wu X, Li ZS, Fu BJ, Zhou WM, Liu HF, Liu GH. Restoration of ecosystem carbon and nitrogen storage and microbial biomass after grazing exclusion in semi-arid grasslands of Inner Mongolia. Ecological engineering 73: 395-403 DOI 10.1016/j.ecoleng.2014.09.077.

Xiong DO, Shi PL, Zhang XZ, Zou CB. 2016. Effects of grazing exclusion on carbon sequestration and plant diversity in grasslands of China-A meta-analysis. Ecological Engineering 94: 647-655 DOI 10.1016/j.ecoleng.2016.06.124.

Xu N, Tan G, Wang HY, Gai XP. 2016. Effect of biochar additions to soil on nitrogen leaching, microbial biomass and bacterial community structure. European Journal of Soil Biology 74: 1-8 DOI 10.1016/j.ejsobi.2016.02.004.

Xu ZH, Ward S, Chen CG, Blumfield T, Prasolova N, Liu JX. 2008. Soil carbon and nutrient pools, microbial properties and gross nitrogen transformations in adjacent natural forest and hoop pine plantations of subtropical Australia. Journal of Soils and Sediments 8(2): 99-105 DOI 10.1065/jss2008.02.276.

Yang N, Ji L, Salahuddin, Yang YC, Yang LX. 2018. The influence of tree species on soil properties and microbial communities following afforestation of abandoned land in northeast China. European Journal of Soil Biology 85: 73-78 DOI 10.1016/j.ejsobi.2018.01.003.

Yang Y, Gao Y, Wang S, Xu D, Yu H, Wu L, Lin Q, Hu Y, Li X, He Z, Deng Y, Zhou J. 2014. The microbial gene diversity along an elevation gradient of the Tibetan grassland. The ISME Journal 8(2): 430-440 DOI 10.1038/ismej.2013.146.

Yao MJ, Rui JP, Li JB, Wang JM, Cao WD, Li XZ. 2018. Soil bacterial community shifts driven by restoration time and steppe types in the degraded steppe of Inner Mongolia. Catena 165: 228-236 DOI 10.1016/j.catena.2018.02.006.

Yates CJ, Norton DA, Hobbs RJ. 2000. Grazing effects on plant cover, soil and microclimate in fragmented woodlands in south-western Australia: implications for restoration. Austral Ecology 25(1): 36-47 DOI 10.1046/j.1442-9993.2000.01030.x.

Yin K, Zhang L, Chen D, Tian Y, Zhang F, Wen M, Yuan C. 2016. Understory herb layer exerts strong controls on soil microbial communities in subtropical plantations. Scientific Reports 6: 27066 DOI 10.1038/srep27066.

Zeng Q, Dong Y, An S. 2016. Bacterial community responses to soils along a latitudinal and vegetation gradient on the Loess Plateau, China. PloS One 11(4): e0152894 DOI 10.1371/journal.pone.0152894. 
775

776

777

778

779

780

781

782

783

784

785

786

787

788

789

790

791

792

793

Zhang RS, Jia SH, Xu GJ, Liu M, Bai XF. 2012. Effects of enclosure on morphological and physical properties of surface soil of Pinus sylvestris var. mongolica plantation on sandy land. Journal of Liaoning Forestry Science and Technology 2: 33-35.

Zhang ZW, Li Q, Zhang HY, Hu YY, Hou SL, Wei HW, Yin JX, Lv XT. 2019. The impacts of nutrient addition and livestock exclosure on the soil nematode community in a degraded grassland. Land Degradation and Development 30(13): 1574-1583 DOI 10.1002/ldr.3344.

Zheng JF, Chen JH, Pan GX, Wang GM, Liu XY, Zhang XH, Li LQ, Bian RJ, Cheng K, Zheng JW. 2017. A long-term hybrid poplar plantation on cropland reduces soil organic carbon mineralization and shifts microbial community abundance and composition. Applied Soil Ecology 111: 94-104 DOI 10.1016/j.apsoil.2016.11.017.

Zhou X, Wang Y, Hao Y. 2012. Short-term rather than long-term exclusion of grazing increases soil bacterial diversity in an Inner Mongolian steppe. Acta Ecologica Sinica 32(4): 180183.

Zhou YP, Lei ZY, Zhou FY, Han YG, Yu DL, Zhang YS. 2019. Impact of climate factors on height growth of Pinus sylvestris var. mongolica. PloS One 14(3): e0213509 DOI 10.1371/journal.pone.0213509.

Zornoza R, Acosta JA, Martínez-Martínez S, Faz A, Baath S. 2015. Main factors controlling microbial community structure and function after reclamation of a tailing pond with aided phytostabilization. Geoderma 245: 1-10 DOI 10.1016/j.geoderma.2015.01.007. 
Figure 1

Venn diagrams of the shared and unique bacterial OTUs (A) and fungal OTUs (B).

AH: Arachis hypogaea; PSM: Pinus sylvestris var. mongolica; PSME: Pinus sylvestris var. mongolica with enclosure. 


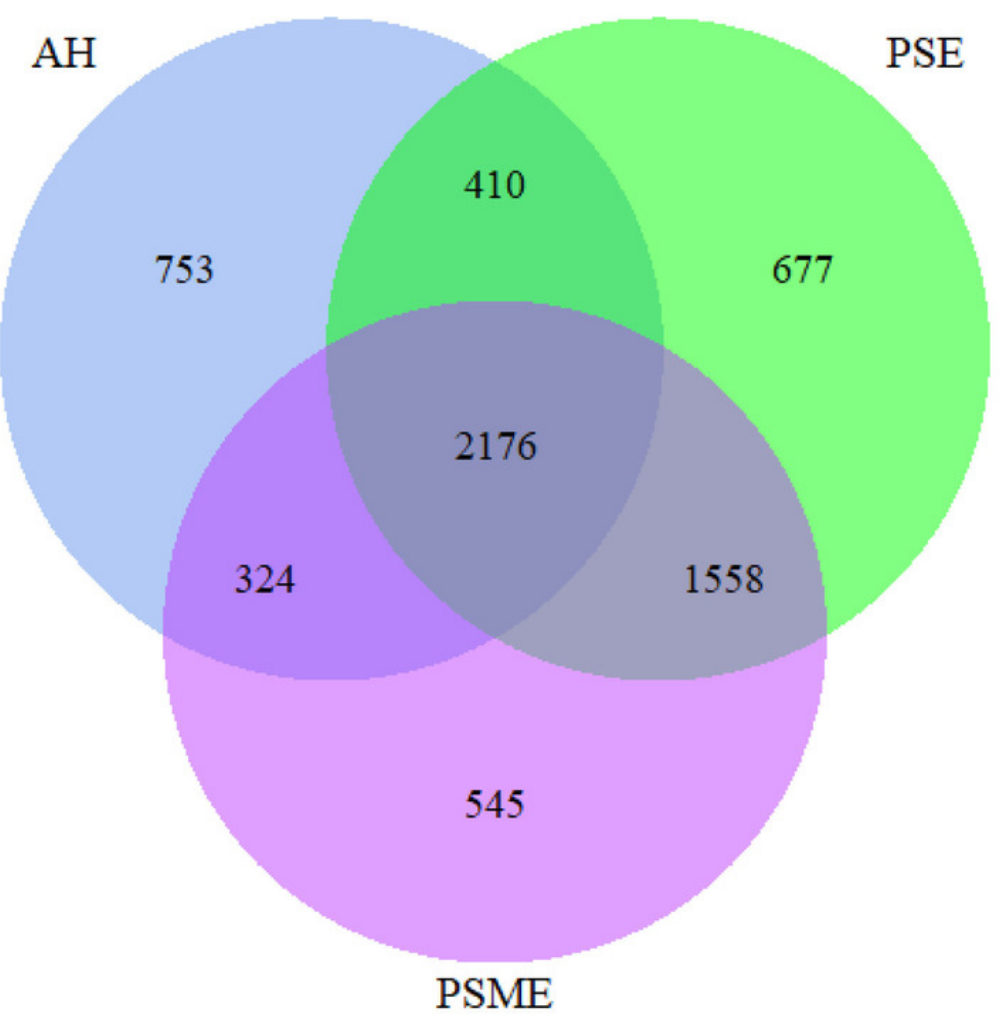

A

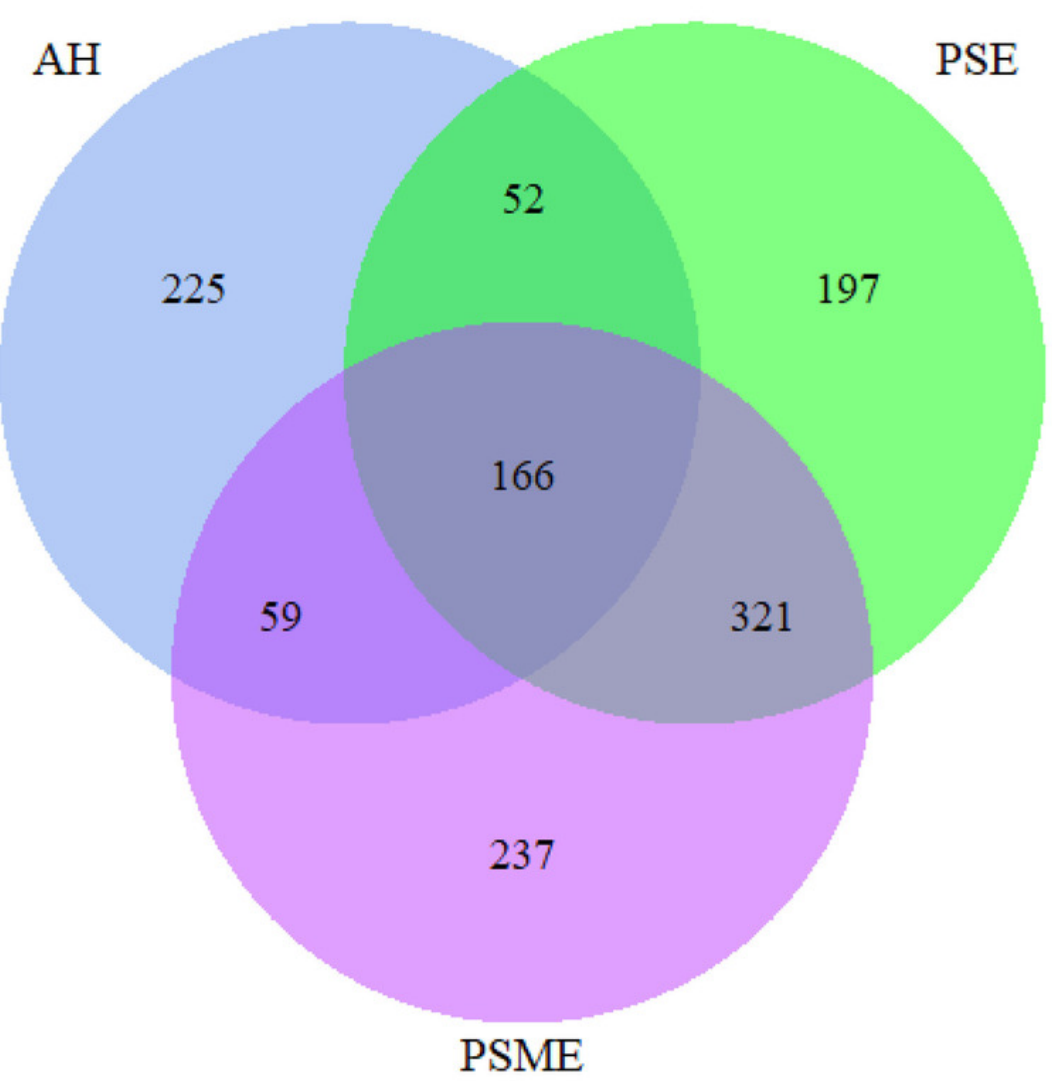

B

Peer] reviewing PDF | (2019:10:42362:1:0:NEW 29 Jan 2020) 
Figure 2

NMDS plots of bacterial OTUs (A) and fungal OTUs (A) based on unweighted and weighted unifrac, respectively.

AH: Arachis hypogaea; PSM: Pinus sylvestris var. mongolica; PSME: Pinus sylvestris var. mongolica with enclosure. 

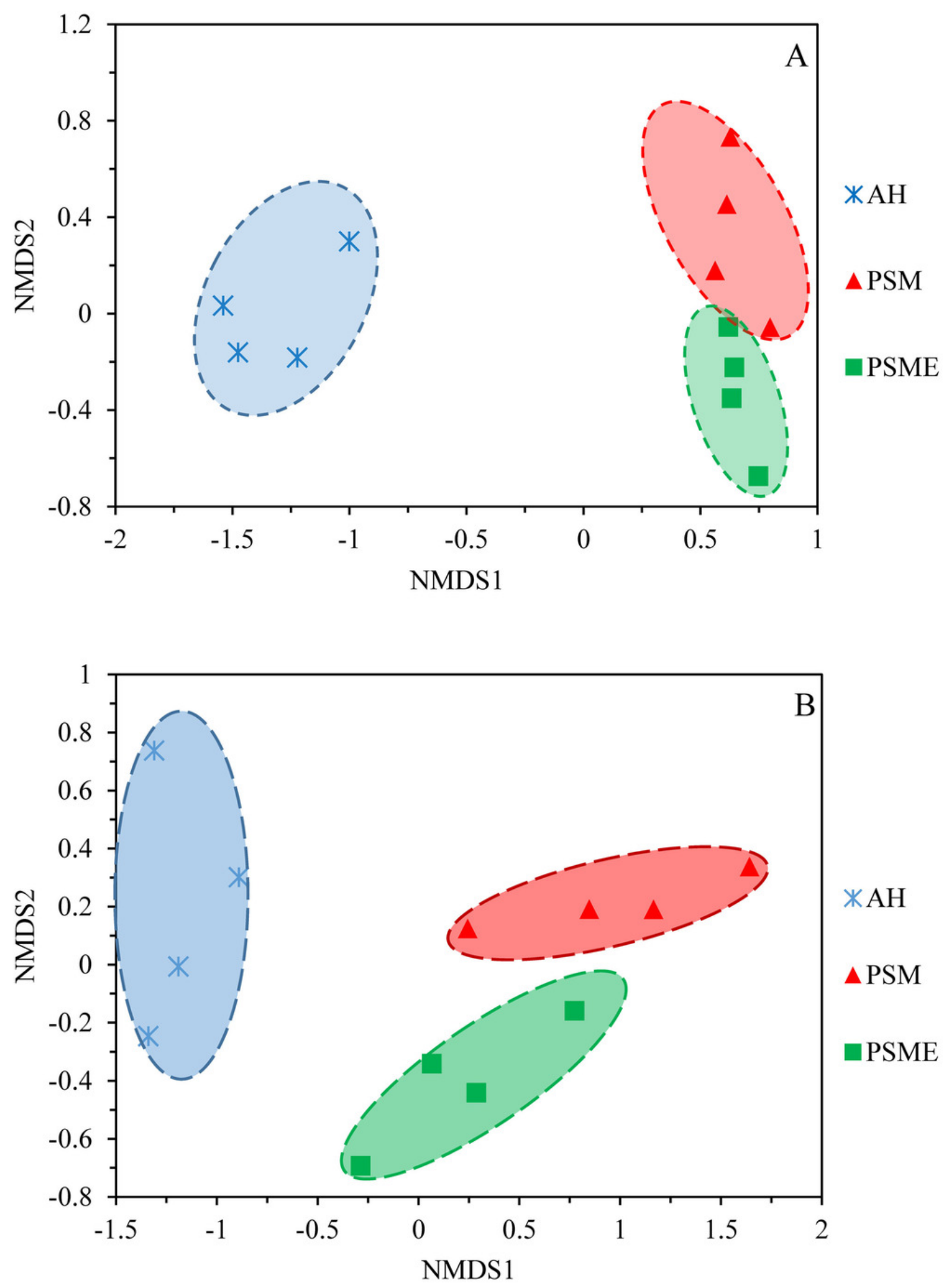


\section{Figure 3}

Spearman's rank correlations between soil characteristics and soil bacterial (A) and fungal diversity indices (B) .

TC: total C; TN: total N; TP: total P; AP: available P; AN: available N; CN: C/N. Blue indicates that the two variables are positively correlated, while red indicates that the variables are negatively correlated. The flatter the ellipse indicates that the absolute value of the correlation coefficient is larger; the rounder the ellipse indicates that the absolute value of the correlation coefficient is smaller. 


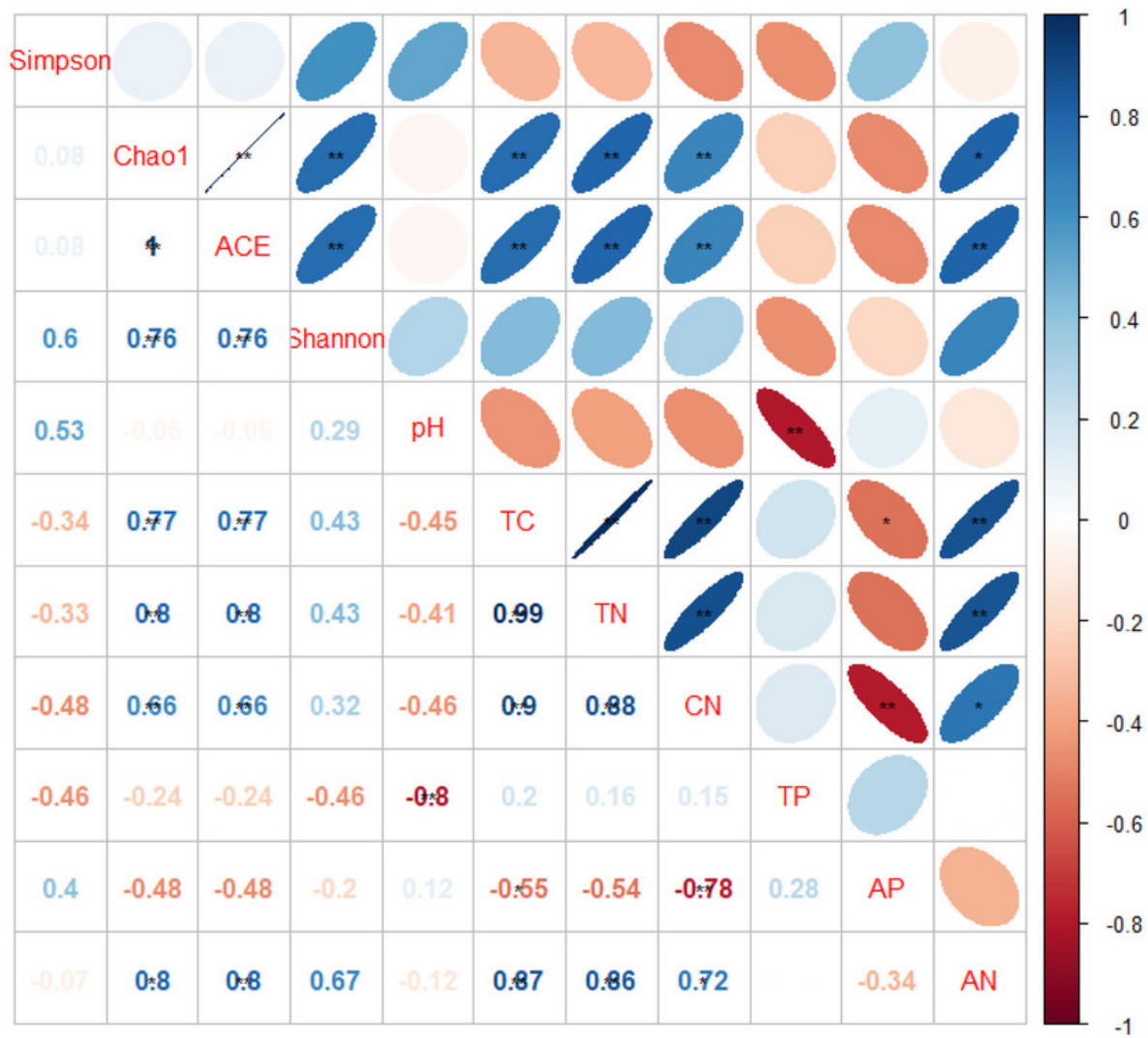

A

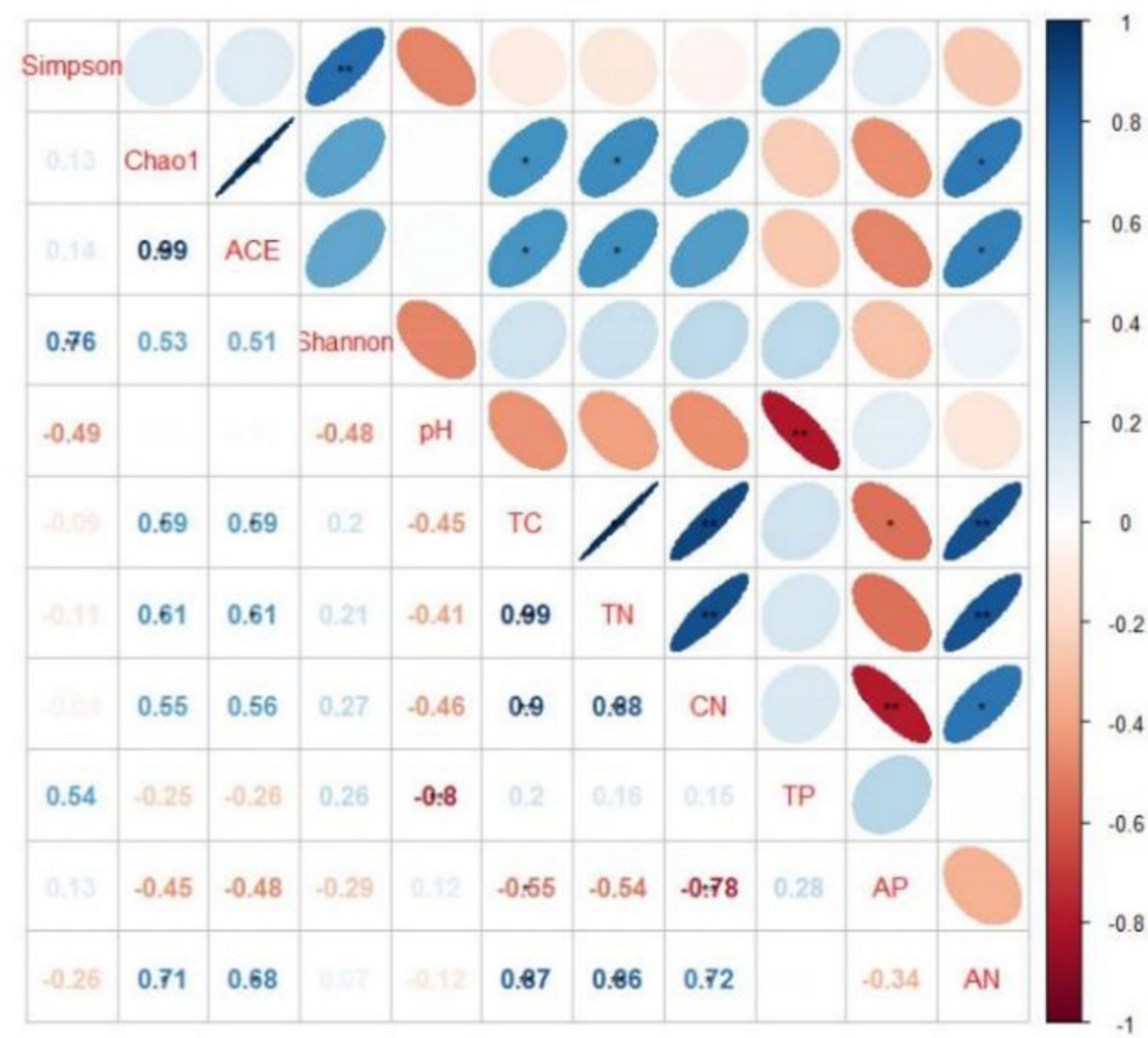


Figure 4

The relative abundances of dominant bacterial (A) and fungal (B) phyla among different samples.

AH: Arachis hypogaea; PSM: Pinus sylvestris var. mongolica; PSME: Pinus sylvestris var. mongolica with enclosure. 

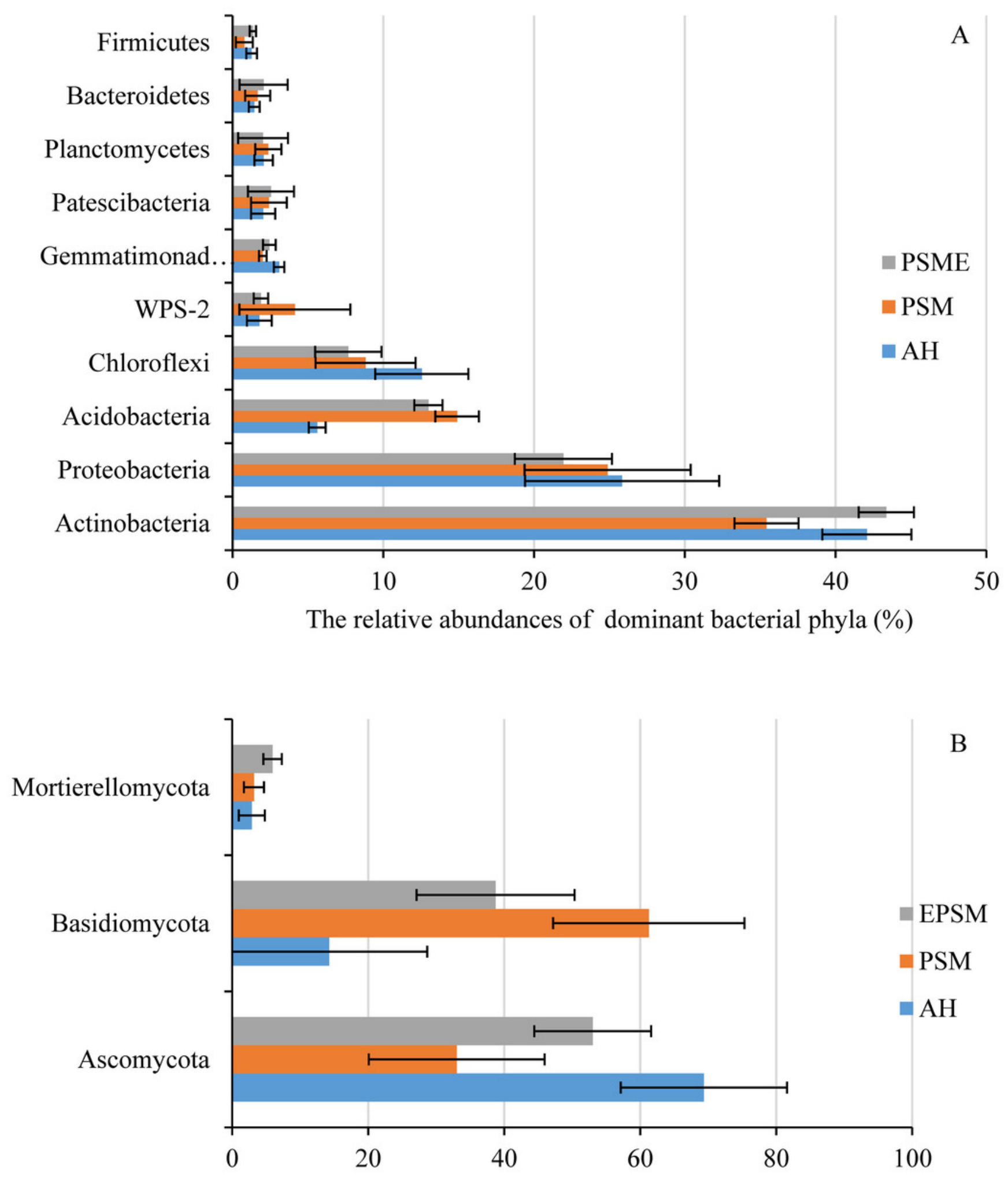

The relative abundances of the dominant fungal phyla (\%) 
Figure 5

The relative abundances of dominant bacterial $(A)$ and fungal $(B)$ genera among different samples.

AH: Arachis hypogaea; PSM: Pinus sylvestris var. mongolica; PSME: Pinus sylvestris var. mongolica with enclosure. 

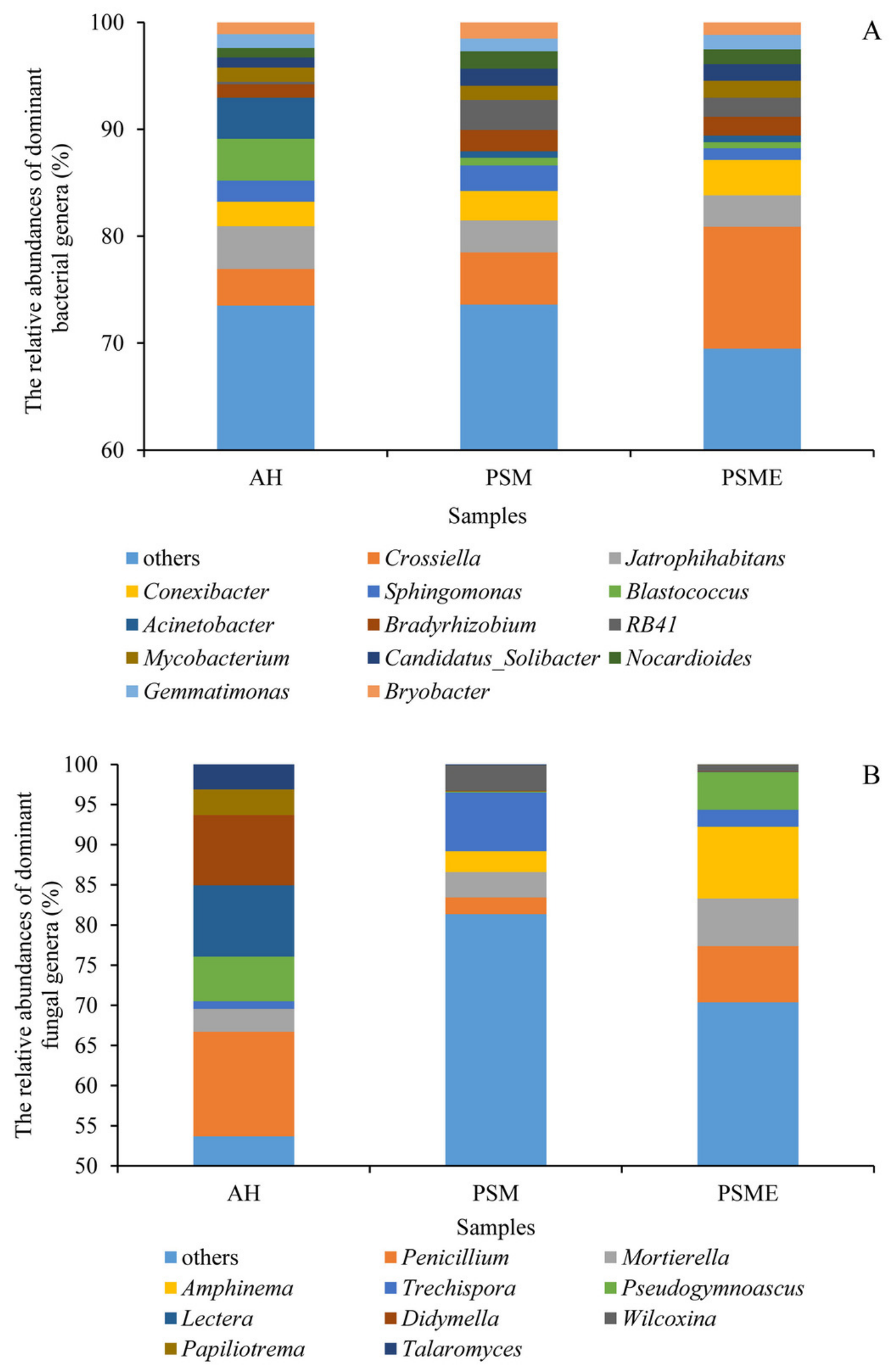


\section{Figure 6}

Heatmap plots of soil bacterial (A) and fungal (B) genera with relative abundances of the top 50 based the bray distance.

AH: Arachis hypogaea; PSM: Pinus sylvestris var. mongolica; PSME: Pinus sylvestris var. mongolica with enclosure. The samples are grouped according to the similarity of each other, and the clustering results are arranged horizontally according to the clustering results. In the figure, red indicates that the genus with higher relative abundance of the corresponding sample, and green indicates that the genus relative abundance of the corresponding sample is low.

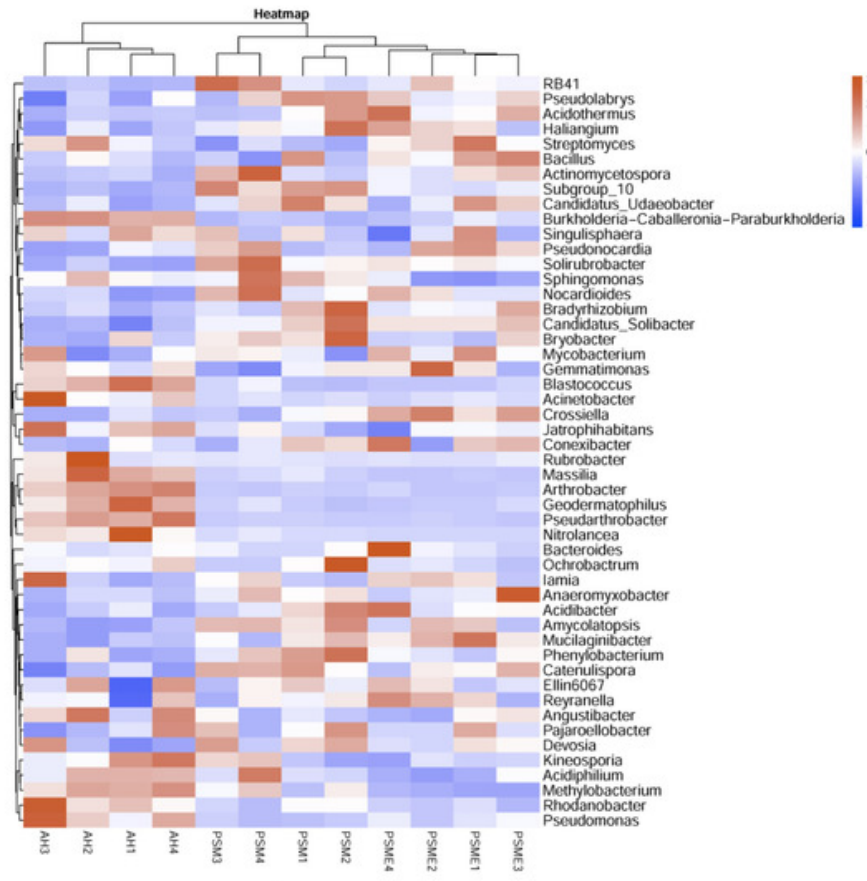

A

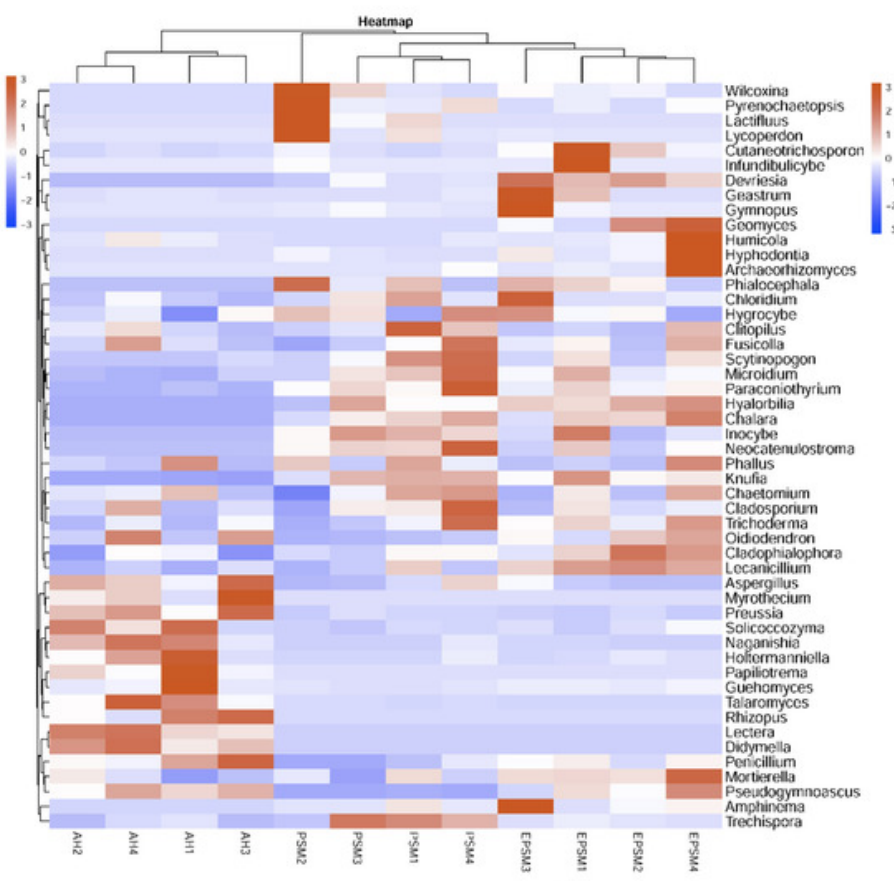

B 


\section{Figure 7}

Redundancy analysis (RDA) between soil environment factors and bacterial (A) and fungal OTUs (B).

TC: total C; TN: total N; TP: total P; AP: available P; AN: available N; C.N: C/N. 

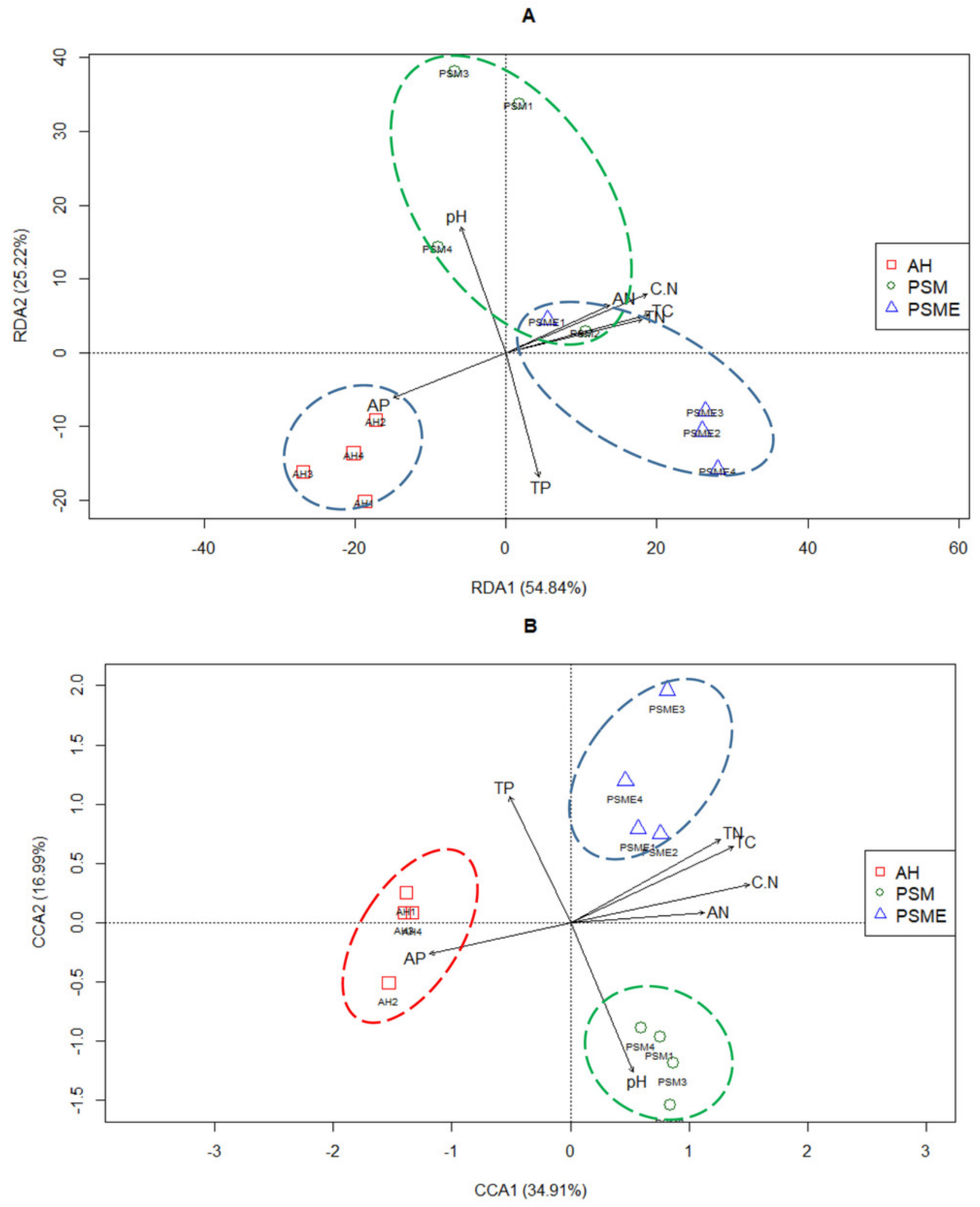


\section{Figure 8}

Network of co-occurring of soil characteristics and dominant bacterial and fungal phyla. A connection stands for a strong (Spearman's $r>0.5$ ) and significant ( $p$-value $<0.01$ ) correlation.

TC: total C; TN: total N; CN: C/N; TP: total P; AN: available N; AP: available P.

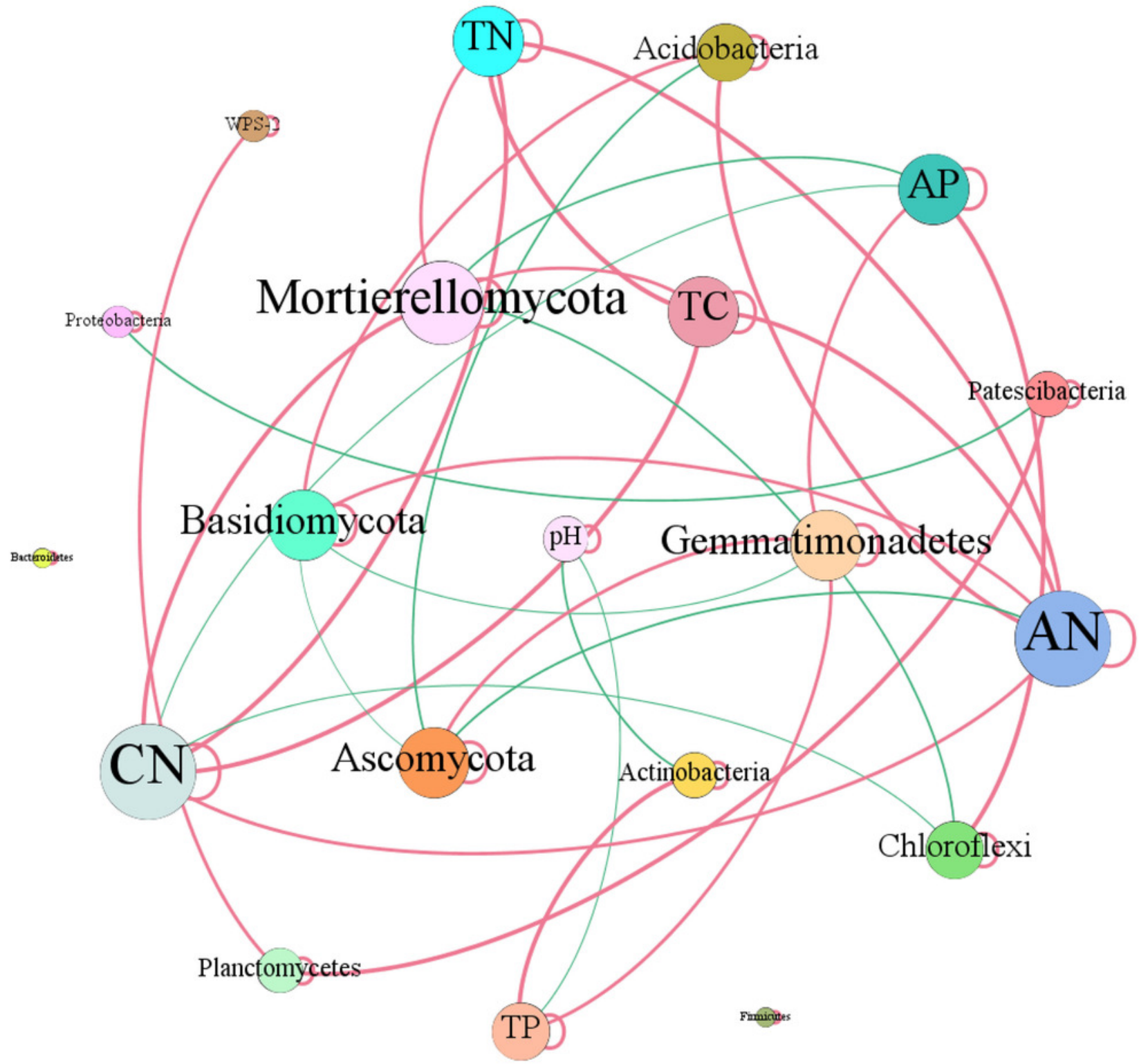




\section{Table $\mathbf{1}$ (on next page)}

Site characteristics.

Note: Measurements of the diameter at beast heigh and tree height did not include regeneration seedlings. PSM: Pinus sylvestris var. mongolica; PSME: Pinus sylvestris var. mongolica with enclosure. 
1 Table 1

2 Site characteristics.

\begin{tabular}{|c|c|c|c|c|c|c|c|c|c|}
\hline \multirow[b]{2}{*}{$\begin{array}{c}\text { Different } \\
\text { samples }\end{array}$} & \multirow[b]{2}{*}{$\begin{array}{c}\text { Plant age } \\
\text { (years) }\end{array}$} & \multirow[b]{2}{*}{$\begin{array}{l}\text { Stand density } \\
\text { (plant } \cdot \mathrm{hm}^{-2} \text { ) }\end{array}$} & \multicolumn{3}{|c|}{ Trees } & \multicolumn{2}{|c|}{ Understory vegetation } & \multirow[b]{2}{*}{$\begin{array}{l}\text { Number } \\
\text { species }\end{array}$} & \multirow[b]{2}{*}{$\begin{array}{c}\text { Surface } \\
\text { litter } \\
(\mathrm{cm})\end{array}$} \\
\hline & & & $\begin{array}{l}\text { Diameter } \\
\text { at Beast } \\
\text { Height } \\
(\mathrm{cm})\end{array}$ & $\begin{array}{l}\text { Tree } \\
\text { Height } \\
\text { (m) }\end{array}$ & $\begin{array}{c}\text { Canopy } \\
\text { density } \\
(\%)\end{array}$ & $\begin{array}{c}\text { Coverage } \\
(\%)\end{array}$ & $\begin{array}{l}\text { Aboveground } \\
\text { biomass }(\mathrm{g} \cdot \mathrm{m} \\
2)\end{array}$ & & \\
\hline PSM & 35 & 495 & 21.63 & 11.55 & $35 \%$ & 90 & 66.02 & 10 & 1 \\
\hline PSME & 35 & $\begin{array}{c}573(48 \\
\text { regeneration } \\
\text { seedlings })\end{array}$ & 24.33 & 12.5 & $37 \%$ & 45 & 120.83 & 25 & 5 \\
\hline
\end{tabular}

3 Note:

4 Measurements of the diameter at beast heigh and tree height did not include regeneration seedlings.

5 PSM: Pinus sylvestris var. mongolica; PSME: Pinus sylvestris var. mongolica with enclosure. 


\section{Table 2 (on next page)}

Soil chemical properties under different treatments.

Note: Data are means (standard error) $(n=4)$. AH: Arachis hypogaea; PSM: Pinus sylvestris var. mongolica; PSME: Pinus sylvestris var. mongolica with enclosure. Different uppercase letters in the same column indicate significant differences at the 0.01 level, and different lowercase letters indicate significant differences at the 0.05 level. 
1 Table 2

2 Soil chemical properties under different treatments.

\begin{tabular}{|c|c|c|c|c|c|c|c|}
\hline $\begin{array}{c}\text { Different } \\
\text { samples }\end{array}$ & $\mathrm{pH}$ value & Total $\mathrm{C} / \mathrm{g} \cdot \mathrm{kg}^{-1}$ & Total N $/ \mathrm{g} \cdot \mathrm{kg}^{-1}$ & $\mathrm{C} / \mathrm{N}$ ratio & Total P $/ \mathrm{g} \cdot \mathrm{kg}^{-1}$ & $\begin{array}{c}\text { Available P } \\
/ \mathrm{mg}^{\mathrm{kg}} \mathrm{kg}^{-1}\end{array}$ & $\begin{array}{c}\text { Available N } \\
/ \mathrm{mg}^{\mathrm{kg}}-1\end{array}$ \\
\hline $\mathrm{AH}$ & $5.68(0.02) \mathrm{bB}$ & $3.96(0.46) \mathrm{cC}$ & $0.57(0.05) \mathrm{cC}$ & $7.00(0.29) \mathrm{cC}$ & $0.169(0.009) \mathrm{aAB}$ & $27.25(2.56) \mathrm{aA}$ & $35.39(2.89) \mathrm{bA}$ \\
\hline PSM & $5.95(0.10) \mathrm{aA}$ & $6.70(0.69) \mathrm{bB}$ & $0.73(0.07) \mathrm{bB}$ & $9.21(0.31) \mathrm{bB}$ & $0.143(0.015) \mathrm{bB}$ & $17.27(6.90) \mathrm{bAB}$ & $43.35(4.45) \mathrm{bA}$ \\
\hline PSME & $5.61(0.05) \mathrm{bB}$ & $8.98(0.50) \mathrm{aA}$ & $0.91(0.06) \mathrm{aA}$ & $9.90(0.19) \mathrm{aA}$ & $0.173(0.010) \mathrm{aA}$ & $15.69(4.40) \mathrm{bB}$ & $46.00(7.08) \mathrm{aA}$ \\
\hline F test & 31.68 & 80.45 & 31.22 & 128.33 & 7.59 & 6.42 & 4.68 \\
\hline P value & 0.0001 & 0.0001 & 0.0001 & 0.0001 & 0.01 & 0.02 & 0.04 \\
\hline
\end{tabular}

3 Note:

4 Data are means (standard error) $(\mathrm{n}=4)$. AH: Arachis hypogaea; PSM: Pinus sylvestris var.

5 mongolica; PSME: Pinus sylvestris var. mongolica with enclosure. Different uppercase letters

6 in the same column indicate significant differences at the 0.01 level, and different lowercase

7 letters indicate significant differences at the 0.05 level. 


\section{Table 3 (on next page)}

Changes in soil microbial diversity under different treatments.

Note: Data are means \pm standard error $(n=4)$. AH: Arachis hypogaea; PSM: Pinus sylvestris var. mongolica; PSME: Pinus sylvestris var. mongolica with enclosure. Different uppercase letters in the same column indicate significant differences at the 0.01 level, and different lowercase letters indicate significant differences at the 0.05 level. 
1 Table 3

2 Changes in soil microbial diversity under different treatments.

\begin{tabular}{|c|c|c|c|c|c|c|c|c|}
\hline \multirow{2}{*}{$\begin{array}{c}\text { Different } \\
\text { samples }\end{array}$} & \multicolumn{2}{|c|}{ Simpson index } & \multicolumn{2}{|c|}{ Chaol index } & \multicolumn{2}{|c|}{ ACE index } & \multicolumn{2}{|c|}{ Shannon index } \\
\hline & Bacteria & Fungi & Bacteria & Fungi & Bacteria & Fungi & Bacteria & Fungi \\
\hline $\mathrm{AH}$ & $0.996 \pm 0.001 \mathrm{aA}$ & $0.94 \pm 0.01 \mathrm{aA}$ & $2111.71 \pm 110.85 b B$ & $268.04 \pm 20.26 \mathrm{bB}$ & $2126.62 \pm 119.64 \mathrm{bB}$ & $271.91 \pm 19.05 b B$ & $9.58 \pm 0.24 \mathrm{bA}$ & $5.44 \pm 0.24 \mathrm{aA}$ \\
\hline PSM & $0.996 \pm 0.001 \mathrm{aA}$ & $0.88 \pm 0.06 \mathrm{bA}$ & $3003.22 \pm 299.64 \mathrm{aA}$ & $388.74 \pm 96.05 \mathrm{aAB}$ & $3047.36 \pm 354.48 \mathrm{aA}$ & $391.94 \pm 95.61 \mathrm{aAB}$ & $10.05 \pm 0.22 \mathrm{aA}$ & $5.08 \pm 1.02 \mathrm{aA}$ \\
\hline PSME & $0.993 \pm 0.002 \mathrm{aA}$ & $0.95 \pm 0.03 \mathrm{aA}$ & $3061.60 \pm 410.84 \mathrm{aA}$ & $413.35 \pm 30.87 \mathrm{aA}$ & $3082.46 \pm 397.57 \mathrm{aA}$ & $419.45 \pm 30.46 \mathrm{aA}$ & $9.87 \pm 0.37 \mathrm{abA}$ & $6.05 \pm 0.71 \mathrm{aA}$ \\
\hline F test & 2.58 & 4.10 & 12.56 & 6.84 & 11.83 & 7.08 & 2.83 & 1.80 \\
\hline P value & 0.13 & 0.054 & 0.002 & 0.02 & 0.003 & 0.01 & 0.11 & 0.22 \\
\hline
\end{tabular}

3 Note:

4 Data are means \pm standard error $(\mathrm{n}=4)$. AH: Arachis hypogaea; PSM: Pinus sylvestris var. mongolica; PSME: Pinus sylvestris var.

5 mongolica with enclosure. Different uppercase letters in the same column indicate significant differences at the 0.01 level, and different

6 lowercase letters indicate significant differences at the 0.05 level. 


\section{Table 4 (on next page)}

VPA of the soil environment factors on microbial community composition. 
$1 \quad$ Table 4

2 VPA of the soil environment factors on microbial community composition.

\begin{tabular}{|c|c|c|}
\hline \multirow{2}{*}{ Soil environment factors } & \multicolumn{2}{|c|}{ The relative contribution (\%) } \\
\cline { 2 - 3 } & Bacterial community composition & Fungal community composition \\
\hline $\mathrm{pH}$ value & $2.60 \%$ & $9.20 \%$ \\
\hline Total C & $4.39 \%$ & $7.94 \%$ \\
\hline Total N & $4.74 \%$ & $7.81 \%$ \\
\hline $\mathrm{C} / \mathrm{N}$ & $2.50 \%$ & $8.21 \%$ \\
\hline Total P & $7.95 \%$ & $7.33 \%$ \\
\hline Available P & $4.64 \%$ & $6.56 \%$ \\
\hline Available N & $3.10 \%$ & $5.56 \%$ \\
\hline
\end{tabular}

3 